\title{
Managerial Attitudes and Corporate Actions
}

\author{
John R. Graham, Campbell R. Harvey, and Manju Puri* \\ Fuqua School of Business, Duke University, Durham, NC 27708, USA \\ National Bureau of Economic Research, Cambridge, MA 02912, USA
}

July 2012

\begin{abstract}
We administer psychometric tests to senior executives to obtain evidence on their underlying psychological traits and attitudes. We find U.S. CEOs differ significantly from non-U.S. CEOs in terms of their underlying attitudes. In addition, we find that CEOs are significantly more optimistic and risk-tolerant than the lay population. We provide evidence that CEO's behavioral traits such as optimism and managerial risk-aversion are related to corporate financial policies. Further, we provide new empirical evidence that CEO traits such as risk aversion and time preference are related to their compensation.
\end{abstract}

JEL Classification: G30, G32, G34

Keywords: Managers, attitudes, personality traits, risk aversion, capital structure, debt, acquisitions, corporate policies, behavioral corporate finance

*Corresponding author, Tel: +1 919.660.7657, Fax: +1 919.660.8030, E-mail: mpuri@duke.edu. We appreciate the comments of Zahi Ben-David, Jack Bovender, Alon Brav, Murillo Campello, Steve Dimmock, Don Durfee, Simon Gervais, Dirk Hackbarth, Bill Holstein, Janet Kersnar, Ahmed Khwaja, Hong Liu, Mary Frances Luce, Pete Nicholas, David Robinson, Antoinette Schoar, Hersh Sheffrin, Meir Statman, Jack Soll, Morton Sorenson, Will Mitchell, David Walonick, Ivo Welch, and seminar participants at ASSA meetings, San Francisco, Case Western University, Duke University, Federal Reserve Bank of Kansas City, Norwegian School of Economics and Business Administration, Bergen, and the 2008 Western Finance Association meetings for helpful comments. We thank Andy Clifton, Kees Koedijk, Peter Roosenboom, Susan Simko and Cheri Varnadoe for their help in implementing the survey, and Chief Executive magazine, $C F O$ magazine, $C F O$ Asia, and $C F O$ Europe for allowing us to survey their subscribers. Special thanks to Martine Cools, Abe de Jong, Frank Ecker, Nadja Guenster, and Bruno Laranjeira for translating the survey. We appreciate the research assistance of Benjamin Ee, Hai Huang, Nikhil Sharma, and Jie Yang. All errors are our own. 



\section{Introduction}

What causes firms to behave the way they do? The answers to this important question are not well understood. Traditional economic theory suggests companies should simply pursue positive net present value projects to maximize shareholder wealth. However, firms around the globe seem to behave differently, leading some to speculate that heterogeneous objective functions are being maximized (see e.g., Allen, 2005). Even within the U.S., firms in the same industry, of similar size and facing similar investment opportunities behave differently.

To what extent do personality characteristics vary among U.S. managers and non-U.S. firms? What is the importance of individual heterogeneity in corporations? The idea that individual heterogeneity matters in corporate finance/governance has recently become a primary focus in behavioral finance. Recent papers suggest that managers matter - there are findings on managerial fixed effects (Bertrand and Schoar, 2003), on managerial overconfidence proxies relating to firm behavior (Malmendier and Tate, 2005, 2008); and on Chief Executive Officer (CEO) characteristics in private equity firms being related to outcome success (Kaplan, Klebanov, and Sorensen, 2010).

We use a survey-based approach to provide new insight into the people and processes behind corporate decisions. This method allows us to address issues that traditional empirical work based on large archival data sources cannot. For example, we are able to administer psychometric personality tests, gauge risk aversion, and measure other behavioral phenomena. Our mode of inquiry is similar to those of experimental economists (who often administer gambling experiments) and psychologists (who administer psychometric tests). As far as we are aware, no other study attempts to measure attitudes of senior management directly through 
personality tests to distinguish CEOs from others and U.S top level executives from non-U.S. top level executives. We also relate $\mathrm{CEO}$ attributes to firm level policies.

Our survey quantifies behavioral traits of senior executives and also harvests information related to career paths, education, and demographics. We ask these same questions of chief executives and chief financial officers, among public and private firms, and in both the U.S. and overseas. We can thus compare traits and attitudes for U.S. and non-U.S. CEOs to see if there is indeed a significant difference in attitudes. We also ask questions related to standard corporate finance decisions such as leverage policy, debt maturity, and acquisition activity. This allows us to relate attitudes and managerial attributes to corporate actions. We also examine how managerial attributes such as risk aversion and time preference relate to compensation at the firm level.

We use the survey responses to address the following broad questions. How do U.S. CEOs differ from lay people, and also how do they differ from Chief Financial Officers (CFOs) and non-U.S. CEOs in terms of behavioral and other characteristics? Are managerial psychological traits, career experiences, or education correlated with corporate decision-making? Do behavioral traits such as risk aversion and time preference explain compensation packages (e.g., does risk aversion actually decrease pay-performance sensitivity as predicted by theory)?

We compare CEOs to CFOs and others in terms of personality traits and career characteristics, as well as make attitude comparisons of CEOs to established norms in the psychology literature. We find that CEOs are much more risk-tolerant than the lay population of similar age profile (studied in Barskey et al., 1997). It is notable that CEOs are also much more optimistic than the lay population as compared to the norms in the psychology literature (Scheier 
et al., 1994). We find, as might be expected, that CEOs and CFOs have different personal characteristics and career paths. Interestingly, we also find significant differences between CEOs and CFOs in terms of attitudes. In particular, our psychometric tests suggest that CEOs are much more optimistic than CFOs. Our results also suggest that U.S.-based CEOs and CFOs are more optimistic than their non-U.S. counterparts. This provides evidence on one channel through which U.S. and non-U.S. firms differ: their executives differ in terms of attitudes and traits, perhaps a reflection of firms outside the U.S. having different norms or maximizing different objective functions (Allen, 2005).

Our paper focuses on CEOs because they are the principal corporate decision makers. In particular, we focus on two key areas that CEOs feel they have the most influence on: mergers and acquisitions and capital structure (see Graham et al., 2012). We investigate which factors and experiences (e.g., personality traits or career path) of the decision maker (CEO) affect capital structure and acquisition decisions. We show that these corporate policies are significantly related to the personality traits of executives. For example, we find that companies initiate more mergers and acquisitions when their chief executive is more risk tolerant. Beyond risk tolerance, one might expect that the level of a chief executive's optimism might be related to the corporate decisions her company makes. For example, optimistic CEOs might expect that recent profitability will continue into the future, or that the future will be better than the recent past. Consistent with this view and the arguments of Landier and Thesmar (2009), we find evidence that optimistic CEOs use more short-term debt than do firms led by less optimistic CEOs. There is also a growing literature that suggests that males tend to be more overconfident than females (see e.g., Barber and Odean, 2001). Correspondingly, we find that male CEOs are more likely to 
have higher debt ratios, and in particular higher short-term debt ratios than their female counterparts.

We find that firms with high historical or future rates of growth are more likely to be run by risk-tolerant CEOs. These chief executives are likely to be younger. They are also more likely to be taller than average. To the extent that height corresponds to confidence (as suggested elsewhere; see e.g., Persicao, Postlewaite, Silverman, 2004, Deaton and Arora, 2009) these results are consistent with more confident, more risk tolerant, younger CEOs being more likely to run growth companies.

We cannot determine the direction of causality between corporate growth and executive personality. Managers may self-select into companies (or companies may hire managers) who have the "right" personality traits for the particular company- What we document is that there is a significant relationship between CEO characteristics and company characteristics

We also examine the CEOs' target compensation in terms of the proportion due to fixed salary, and separately the part that is performance dependent, i.e., bonus, stock and options. We find that risk averse CEOs are significantly more likely to be compensated by salary and less likely to be compensated with performance related packages. We further find that CEOs who are impatient (i.e., have a high rate of time preference) are more likely to be paid proportionately more in salary. These results are intuitive. Standard agency theory, including both screening/adverse selection models and moral hazard models, predicts a fundamental trade-off between increasing incentives and risk, i.e., the more risk averse the agent, the more costly it is to provide pay-performance incentives. Despite this, it has been very hard to find support for this prediction in the empirical literature (see e.g., Prendergast, 2002). Our finding that pay- 
performance sensitivity actually decreases with risk aversion is, to our knowledge, one of the first direct pieces of evidence consistent with this theoretical prediction. Further our findings that differences in time preference are also important for explaining compensation patterns is consistent with standard agency theory but is a prediction that has largely been ignored in the literature. Our results that CEOs are on average much less risk-averse than the general population also fits well with this framework. Risk-aversion makes incentive pay costly, and increases the participation constraint of the manager. As a result, firms prefer to hire less riskaverse agents as managers, all else equal.

While the survey approach allows us to ask many unique questions, it is not without potential problems. Surveys measure beliefs, not necessarily actions. Perhaps some of the survey questions are misunderstood or otherwise produce noisy measures of the desired trait or characteristic. Moreover, at least for some questions, executives can potentially parrot explanations that they think researchers want to hear, rather than state their true beliefs. In addition, field studies may face the objection that market participants do not necessarily have to understand the reason they do what they do in order to make (close to) optimal decisions. It is also possible that the respondents are not representative of the underlying population, an issue that we investigate below. Given that we conduct our survey at one point in time, it is not possible to determine causation for the most part. For example, we cannot say for sure whether risk-tolerant CEOs use less short-term debt or whether firms that have a policy of using shortterm debt attract less risk-tolerant employees. Likewise, in most cases, it is not possible for us to distinguish whether the personality trait causes the corporate policy from whether an executive "learns" a trait on the job, nor can we separate a managerial fixed effect from a company fixed 
effect. In the latter case, a company might optimally seek out an executive with certain traits due to the needs of the business. Indeed, our results are consistent with such an interpretation.

Even with these considerations, our study provides new insights and contributes to several different research streams. First, we administer the first-ever psychometric tests of sitting executives and provide evidence that U.S. CEOs differ significantly from non-U.S. CEOs in terms of attitudes and attributes, from CFOs, and also from lay population. The differences in attitudes help provide one possible rationale for differences in firm behavior across countries. Second, we contribute to the literature that investigates whether executives' characteristics and psychological traits are related to corporate decisions. Third, our results provide direct evidence on a role for risk aversion and time preference in executive compensation - a result predicted by standard agency theory but one on which direct evidence has been scarce.

The rest of the paper is organized as follows. Section 2 describes the survey instrument that we use, and explains the design of the questions and delivery mechanism. Section 3 presents our analysis of who makes which decision within the firm, how managerial traits correspond to corporate actions, whether there is matching between companies and managers, and the differences between CEOs and others. Some conclusions are offered in the final section.

\section{Method}

\subsection{Survey mechanism}

A common approach used in prior work is to infer executive attitudes from observed executive actions. While this is a laudable technique, questions arise about the validity of the action as a broad-based proxy, and samples are limited to companies for which such managerial 
actions are observable. We adopt a different approach in which we gauge managers' personality traits and attitudes using well-established questions that have been shown in psychology and economics to be valid measures of peoples' attitudes.

To assess risk aversion, we examine managers' responses to a series of gambles similar to Barsky et al. (1997), who administer such questions in the Health and Retirement Survey. To assess optimism, we borrow from well-established psychology literature using standard psychometric tests (Scheier and Carver's Life Orientation Test Revised or LOT-R test) that have been widely used in psychology research. To measure time preferences, we assess time predilection for gains and losses. To gauge sure loss aversion, we present managers with a gamble that, if rejected, indicates that they are averse to sure losses.

As far as we are aware, no other study attempts to measure attitudes of senior management directly through such personality tests and relate them to firm level policies. In addition, because the survey is anonymous we also gather information on other measures and variables thought to be important, as described below.

\subsection{Survey Design}

Our survey is wide ranging, our hope being to capture many facets of corporate decision making. Our survey was designed to address multiple issues, including how attitudes of senior management relate to firm level policies. ${ }^{1}$ Below we focus on the key variables that we use in this study and how they are created.

\footnotetext{
${ }^{1}$ In a companion paper (Graham et al., 2010), we examine how capital is allocated, and decision-making authority is delegated, within firms, and use several questions from the survey that are not studied in this paper.
} 


\subsubsection{Measuring attitudes}

Personal risk aversion: We follow the approach in Barsky et al., 1997, to measure personal risk aversion. In their paper, Barsky et al. use survey methods to measure risk aversion in the Health and Retirement Survey, which involves over 11,000 responses from adults aged 51 to 61 . The principal requirement for a question aimed at measuring risk aversion is that it must involve gambles over lifetime income. The nature of the questions in Barsky et al. is as follows:

Suppose that you are the only income earner in your family, and you have a good job guaranteed to give you your current (family) income every year for life. You are given the opportunity to take a new and equally good job, with a 50-50 chance it will double your (family income) and a 50-50 chance that it will cut your (family) income by a third. Would you take the new job?

Barsky et al., 1997, caution that because changing jobs is costly, there may be a status quo bias that would predispose an individual to reject the risky alternative. This is also discussed in Shefrin, 2005. Accordingly, we modify the Barsky et al. approach, rewording the question as a choice between two alternative new jobs, one with a safe income stream, the other being risky. The series of questions that we use is:

Suppose you are the only income earner in your family. Your doctor recommends you move because of allergies. You have to choose between two possible jobs (choose one):

(a) $100 \%$ chance that the job pays your current income for life

(b) $50 \%$ chance that the job pays twice your current incomes for life and $50 \%$ chance that the job pays $2 / 3$ of your current income for life.

If the respondent picked (a), the survey continues to ask: 
Which job would you choose if the choices were instead:

(c) $100 \%$ chance that the job pays your current income for life.

(d) $50 \%$ chance that the job pays twice your current incomes for life and $50 \%$ chance that the job pays $4 / 5$ of your current income for life.

If the respondent picked (b), the survey continues to ask:

Which job would you choose if the choices were instead:

(e) $100 \%$ chance that the job pays your current income for life.

(f) $50 \%$ chance that the job pays twice your current incomes for life and $50 \%$ chance that the job pays $1 / 2$ of your current income for life.

In our analysis, we classify people who answer (a) and (c) as being the least risk-tolerant.

\section{Optimism}

We measure optimism using psychometric tests specifically designed to gauge optimism. In particular we use the Life Orientation Test - Revised (LOT-R), as devised by Scheier et al., 1994. The LOT-R has been used extensively in the psychology literature; ${ }^{2}$ it has the advantages that it is a very credible measure in psychology, it is brief and easy to use, and has a well established interpretation. Its brevity makes it ideal for use in a survey such as ours where questionnaire length is an important consideration.

In this test, respondents are asked to answer a number of questions on a $0-4$ point scale ranging from "I agree a lot," "I agree a little," "I neither agree nor disagree," "I disagree a little,"

\footnotetext{
${ }^{2}$ References to articles that use LOT-R can be found at http://www.psy.miami.edu/faculty/ccarver/sclLOT-R.html and in Puri and Robinson, 2007.
} 
and "I disagree a lot." There are 10 questions: six pertinent questions with four filler questions. The six scored questions are:

1. In uncertain times, I usually expect the best.

2. If something can go wrong for me, it will.

3. I'm always optimistic about my future.

4. I hardly ever expect things to go my way.

5. I rarely count on good things happening to me.

6. Overall, I expect more good things to happen to me than bad.

Coding is done so that high values indicate optimism. Thus questions 1, 3, 6 are numerically coded with a 4 if the respondent answers "I agree a lot" and 0 if they answer "I disagree a lot." Questions, 2, 4, and 5 are coded as 4 if the respondent answers "I disagree a lot," and 0 if the respondent answers "I agree a lot." This gives us a range of mean responses from 0 4. We classify as optimistic respondents who average 3 or higher for these questions.

\section{Time preference}

We ask the following question to measure time preference for gains (see e.g., Loewenstein, Read and Baumeister, 2003):

Would you rather win US\$10,000 now or win US\$13,000 a year from now?

If the respondent answers that s/he would rather win US\$10,000 today, s/he is categorized as being impatient because s/he has an implicit discount rate of more than $30 \%$. 
If an executive is averse to sure losses then this may lead her/him to undertake actions such as "throwing good money after bad" in hopes of turning around what appears to be a sure loss. We pose the following question to measure aversion to sure losses:

Last year your company invested $\$ 5$ million US in a project that was expected to generate cash flows of $\$ 10$ million US after one year. A year has passed and the project yielded nothing.

Now you have the opportunity to invest an additional sum in this same project. There is a $20 \%$ chance that the project will generate a $\$ 10$ million US cash flow in a year's time and nothing thereafter. There is an $80 \%$ chance that the new investment will generate nothing at all. How much would you be willing to invest today?

$\$$ million dollars US.

If the respondent replies $\$ 2$ million or more we classify her/him as averse to sure losses because this action indicates a willingness to overpay to continue the project in order to avoid the "sure loss" of terminating the project today.

\subsubsection{Demographics/career related variables}

This is an anonymous survey, hence we gather information on the personal characteristics of the executives, their past career/education, and related demographics since past work suggest they can be important, and we therefore incorporate them as controls. We collect information on height, gender, age, past experience, whether they obtained an MBA, and whether they graduated 
from a prestigious college. We briefly describe the rationale behind these variables and their construction below.

Height: Economists have documented a height-wage disparity that is almost of the same magnitude as the gender wage disparity (see e.g., Persicao, Postlewaite, Silverman, 2004). One explanation given for this disparity is that height, especially in the adolescent years, is important in developing confidence, which ultimately translates into the wage disparity. (For example, the (tall) star athlete has his confidence built up during his youth, as coaches and other adults laud his accomplishments; this confidence carries over into other aspects of the athlete's life.) This literature would suggest that height might be a reasonable proxy for confidence. Case and Paxson (2008) suggest that height might proxy for cognitive ability. Accordingly, height might capture something that our behavioral questions do not. We define a male to be tall if he is $5 \mathrm{ft}$ 10 inches or above, and a woman is tall if she is $5 \mathrm{ft} 4$ inches and above, both of which are one inch greater than the average adult height among U.S. residents.

Male: There is a growing literature that suggests that the degree of confidence differs between men and women, and that men tend to be more overconfident (see e.g., Barber and Odean, 2001).

MBA: An MBA degree can signal many things. It can represent valuable knowledge gleaned from a good business education. On the other hand, it might indicate conservatism as those who really want to shoot for the stars early on might decide that a MBA is not necessary. ${ }^{3}$

Age: An executive's age can potentially affect decisions in important ways. Younger CEOs may be bolder. On the other hand, age can reflect experience and perspective, allowing

\footnotetext{
${ }^{3}$ In contrast, Chevalier and Ellison (1999) find that fund managers with MBAs tend to take on more systematic risk.
} 
executives to take more risks. Some evidence suggests that personal risk aversion appears to increase with age till age 70 and then decline (see Shefrin, 2005). There is also some evidence that the sophistication of financial decisions varies with age (see Agarwal et al., 2007).

Past experience: The executive's career path (whether their background is from finance, accounting, legal, sales/marketing, or other routes) could affect outlook and comfort level in certain kinds of decisions. Accordingly, we ask the respondent whether his/her work experience prior to becoming an executive was primarily in operations, legal, sales/marketing, accounting, finance/treasury, research, or other.

Prestigious College: Graduating from a college with high SAT scores can be a sign of innate intelligence. It is also possible that graduating from a prestigious college endows certain expectations on the kind of work that one does and the kind of company that one joins. Accordingly, we use SAT scores of the colleges that the executives attend to gauge how prestigious the school is. The methodology we employ is similar to Chevalier and Ellison (1999). ${ }^{4}$

\footnotetext{
${ }^{4}$ Ideally, we would like to know the SAT score of the school at the time that the CEO attended; our computed SAT scores are an approximation for this. We follow Chevalier and Ellison (1999) methodology, which briefly, is as follows. We use Lovejoy's College Guide as our main source for SAT scores. Where there is a range of SAT scores we take the midpoint of the middle $50 \%$ of freshmen scores as reported in Lovejoy's College Guide. If the middle $50 \%$ is not available we take the average SAT scores or ACT scores at the university. For $64 \%$ of our sample the scores are calculated directly. For the rest, we approximate: if only mean SAT scores are available then we use the sum of the mean math and verbal scores. Some schools report ACT mid 50\% range only. For these we construct predicted values from a regression of SAT math high on ACT math low, ACT math high, ACT math low squared and ACT math high squared. If only the average ACT math and reading scores are reported then we rerun similar regressions using the midpoint of the SAT-50 percent ranges as the dependent variable and the midpoint of the ACT-50 percent ranges and the midpoint squared as independent variables. If only composite ACT scores are reported, then we use them as if they represent only reading and math scores and rerun the above regressions. If only selectivity scores are reported then we assign to these schools the mean SAT score of the schools with the same selectivity index. Insofar as in mid-tier schools the CEO is likely to be in the right tail of the distribution, the median SAT scores from such schools are likely to understate CEO's personal SAT score.
} 


\subsubsection{Company characteristics}

We collect information on a number of company characteristics. We are unable to match to Compustat data since the survey does not require companies to identify themselves; hence we collect company specific data in the survey itself. The purpose is to determine whether we can identify a relation between personal or demographic information and corporate actions. Additionally we search for evidence consistent with a matching of executives and companies. Accordingly we gather the following information.

Size: The size of the firm can be important for a variety of reasons. Large size can imply a certain amount of stability and has implications for growth. Research suggests that large firms typically have more debt (Frank and Goyal, 2007). Hence, we control for size in our tests. Large firms are defined as those with sales revenues exceeding $\$ 1 \mathrm{~B}$.

Operating Segments: The number of operating segments of the company tells us something about diversification. Accordingly one of the questions in the survey is how many operating segments (i.e., distinct operating divisions like autos, food and retail) does your company have?

Public or Private: We ask respondents to indicate whether their firm is public or private. This is an important characteristic of the company in its own right, and can be related to some corporate decisions, e.g., acquisition activity.

Debt Ratio: The amount of debt that a company uses is the subject of much discussion in finance and behavioral economics. One consideration important to our analysis is that using more debt "levers up" the firm, producing more risk and higher expected returns, a preference 
which might be related to executive personality traits. Hence we ask respondents to indicate the total debt/total assets ratio for their companies.

Short Term Debt Ratio: Some theories suggest that behavioral characteristics matter more for short term debt as opposed to the total debt undertaken by the firm (see e.g., Landier and Thesmar, 2009). Accordingly, we ask for the short term debt/total debt ratio for the firm.

Number of Acquisitions: Dating back to Roll's (1986) Hubris Hypothesis on takeovers, many argue that acquisitions are often driven by managerial characteristics as opposed to being purely value-maximizing transactions. The large literature on bidder returns, which are near zero or negative on average, is consistent with such a story (see e.g., Andrade, Mitchell, and Stafford, 2001). Accordingly, one of our objectives is to investigate whether managerial characteristics are related to acquisition activity. Hence we ask about number of acquisitions as well as amongst the management team who has most of the input in mergers and acquisitions. The survey design allows us to identify the subset of CEOs who believe they are the dominant M\&A decision maker. For this purpose we use the question: "Amongst the management team, who has most of the input in mergers and acquisitions." The CEO answers based on a 7 point scale, where 1 represents "I make decision without help from others," 7 represents "others make decisions," and the mid-point is "share decision equally with others."

Historic Growth: We are interested in investigating the types of companies for which different sorts of managers work. If there is some matching of managerial traits to company characteristics, rapidly growing companies would be a logical place to see such matching. Hence, we ask the executives to report average annual sales revenue growth rate for their company over the last three years. 
Expected Growth: Presumably, it is not just historical growth that is important but future anticipated growth as well. Hence we also ask managers to project the annual growth rate in sales for their companies over the next three years.

Compensation: Executives arguably have some discretion about the composition of their compensation packages. All else equal, managers with certain characteristics (e.g., high risk aversion) would prefer all else equal compensation packages with a larger salary component and a smaller variable component. In any given year, these components might vary. Hence we ask managers about the target percentage of their total compensation that is in the form of salary, bonus, stock and options awards, and other.

\subsection{Survey Delivery}

We created an initial survey instrument based on existing theoretical and empirical research. We then solicited feedback from a number of academics, practitioners, and CEOs on the initial version of the survey. Based on this feedback, we shortened and focused the survey. We also sought and incorporated the advice of marketing research experts on the survey's design and execution. A PDF of the faxed English language version of the final survey instrument can be found at http://faculty.fuqua.duke.edu/ jgraham/CEOCFO.pdf. For most of the participants, rather than a fax, the version of the survey they were administered consisted of a series of linked HTML pages.

We survey both CEOs and CFOs. We contacted three groups of CEOs. The largest group was approximately 10,000 executives who subscribe to Chief Executive magazine. Chief Executive has more than 70,000 subscribers, and we emailed an invitation to participate in the 
survey to the CEO subscribers who work at the largest 10,000 companies (among their 70,000 subscribers). There was a bounceback rate of about 2.3 percent on the emails, meaning that approximately 9,770 executives received the invitation. We also reached out to readers of Chief Executive with an advertisement in the magazine that invited them to go to an Internet link to participate in the experiment. This printed advertisement attracted fewer than two dozen participants, and if we were to delete these CEOs from the sample our results do not change. Due to their small number, we do not separate out these CEOs for the remainder of the paper but instead merge them in with the other Chief Executive respondents.

The second group of CEOs we contacted is 800 (net of bounced emails) chief executive readers of $C F O$ magazine. We emailed the same survey invitation to these executives. The third group of CEOs attended the World Economic Forum in Davos during January 2005. We faxed surveys to 142 Davos' executives and received seven responses. If we were to delete these responses, it would not alter our results. Due to their small number, we do not separate out these CEOs for the remainder of the paper.

In total, we surveyed approximately 10,700 CEOs, once improper email addresses are eliminated. All of these invitations were issued on approximately February 1, 2006. We sent a reminder to all those emailed on February 14th. Across all these groups, 1,180 CEOs responded, for a response rate of approximately $11 \%$, which is typical of recent survey response rates. ${ }^{5}$ In the analysis below, we focus primarily on the 1,017 CEOs who work for firms headquartered in the United States.

\footnotetext{
${ }^{5}$ Graham et al. (2005) obtain a response rate of 10 percent, Trahan and Gitman (1995) 12 percent, Graham and Harvey (2001) 9 percent, and Brav et al. (2005) 16 percent. In addition, Slemrod and Venkatesh (2002) survey tax preparers (12 percent response rate) and corporate taxpayers ( 9 percent response rate) about compliance costs. The referenced quarterly CFO survey can be found at http://www.cfosurvey.org.
} 
During the first two weeks of February 2006, we also invited four groups of U.S. CFOs to participate. ${ }^{6}$ The largest group of surveyed CFOs consists of subscribers to $C F O$ magazine. On our behalf, the magazine emailed 6,800 invitations (net of bounced emails) to subscribers of the U.S. version of its primary publication, $C F O$ magazine. Separately, Duke University emailed 2,000 (net of bounced emails) CFOs who had participated in previous quarterly CFO Global Business Outlook surveys conducted by researchers at Duke and CFO (see http://www.cfosurvey.org). The response rate for the quarterly survey is typically 5 to 6 percent. The third group was 253 CFOs who participated in the Forum on Corporate Finance. Finally, 107 financial officers who are alumni of Duke University were faxed a survey instrument (the results do not change if faxed responses are ignored). All total, approximately 9,000 US-based CFOs were surveyed. We received 549 responses, for a response rate of approximately $6 \%$.

We also surveyed Asian and European chief financial officers. In particular, we invited subscribers to $C F O$ Europe and $C F O$ Asia magazines to participate. In the demographic questions, we verify that these respondents in fact work in firms that are headquartered in these geographic regions. $C F O$ Europe sent approximately 5,600 email invitations and $C F O$ Asia 4,500, both figures net of emails that bounced. 396 European CFOs responded, as did 264 Asian CFOs, yielding response rates of approximately $7 \%$ and $6 \%$, respectively. The Asian group was not sent an email reminder because the reminder date fell near the Chinese New Year. The European response rate may be a little higher because we gave the executives the opportunity to take the survey in any of four languages: English, French, German, or Dutch. The Asian survey was only available in English. Overall, we had 1,276 CFOs respond across different regions. In

\footnotetext{
${ }^{6}$ Most of those surveyed have the job title CFO. Some have the title of Treasurer, Assistant Treasurer, VP Finance, Comptroller, or a similar title. We refer to this group collectively as CFOs.
} 
this paper, the non-U.S. executives and CFOs are primarily included as a comparison group for executive personality traits and characteristics.

\subsection{Summary statistics}

Table 1, panel A contains self-reported summary information about the characteristics of sample firms. In our sample $11.5 \%$ of the firms are public, with mean sales revenue of $\$ 551$ million. While much research studies public firms, one advantage of our sample is that we learn a great deal about private firms. This is important because little private firm research is conducted even though $87 \%$ of U.S. firms with assets greater than $\$ 10$ million are private. ${ }^{7}$ At the same time, it is important to interpret our results with the public/private breakdown in mind.

We gather a number of demographic characteristics of the CEOs relating to personality traits as well as career and education. Some summary statistics about CEOs are given in Table II, panel A. In our sample, $9.8 \%$ of U.S. CEOs have low risk tolerance. Thus most CEOs seem willing to take on risk, which is perhaps a necessary ingredient of the job that CEOs undertake. Or, perhaps risk-takers that succeed are the "winners" who ultimately rise to the CEO position.

In our sample, $80.2 \%$ of the CEOs are very optimistic as gauged by the LOT-R test. CEOs are very optimistic in absolute terms, and also as compared to CFOs and as benchmarked against the norms in the psychology literature (see Scheier et al., 1994). We discuss the differences further in Section 3 below.

More than one-third of CEOs have a MBA degree. They are predominantly male (92.3\%). The median male height is 71 inches while the median female height is 66 inches. One-third are

${ }^{7}$ http://spccapital.com/FAQS.1.6-1.htm\#FAQ12 
impatient in terms of having a discount rate greater than $30 \%$. In terms of career path, $16 \%$ of the sample comes from a finance/accounting background. The mean CEO is 54 years old and attended a university with a mean SAT score of 1160.

\section{CEO characteristics}

In this section, we compare the personality traits of CEOs to other people. For example, how similar are they to CFOs or to the general population?

\subsection{Comparisons between U.S. CEOs, U.S. CFOs, and non-U.S. executives}

For risk aversion, we have a benchmark from the Barsky et al. (1997) study. Our survey uses similar questions to Barsky et al. on risk aversion but we find very different results. Barsky et al. posed these questions in the Health and Retirement Study (HRS), which had a mean respondent age of 55.6 years. Our mean CEO age is roughly similar at 54.1 years. In Barsky et al., over $64 \%$ of the respondents are reported to display low risk tolerance. In sharp contrast, we find that only $9.8 \%$ of our CEOs display low risk tolerance.

CEOs are likely to have larger wealth than the lay population, which could affect some measures of risk tolerance. However, as Barsky et al. (1997) show, one can back out the coefficient of relative risk aversion from the questions, and this measure of risk aversion should not be a function of wealth. For the very risk averse, on which we focus, the coefficient of relative risk aversion is greater than $3.76 .{ }^{8}$ Our results suggest that $9.8 \%$ of CEOs have a relative risk aversion greater than 3.76 as compared to $64 \%$ of similar aged lay population. CEOs are

\footnotetext{
${ }^{8}$ As explained in Section 2, our question is slightly different from that in Barsky et al. (1997). Our very risk averse category corresponds to Category I in Table I in Barskey et al.
} 
often perceived to be visionaries and risk-takers. Our results of very large differences in the degree of risk aversion between CEOs and the lay population support this popular wisdom

We are also able to benchmark the dispositional optimism of U.S. CEOs against a number of measures. The U.S. CEOs in our sample are highly optimistic. They have a mean LOT-R score of 20.34 (standard deviation of 3.50). Benchmarking this against the norms in the psychology literature, Scheier et al. (1994) find a mean LOT-R score of 14.33-15.15 (standard deviation of 4.05-4.33). 80 percent of our CEOs are very optimistic (mean score of 18 or more, or average score of 3 or more on a $0-4$ range), well above the mean in the psychology literature norms. Interestingly CEOs are much more optimistic than CFOs, with only 65 percent of CFOs being classified as very optimistic.

Given our results that CEOs are optimists as per psychometric tests, a related question is whether others also perceive CEOs to be optimistic. In order to assess this we conduct another survey in March 2007. In this survey, we ask CFOs about their perception of CEO optimism. The specific question we ask is "Compared to your level of optimism, is the CEO of your company more or less optimistic about the financial prospects of your own company?" CFOs can respond whether their CEO is more optimistic, less optimistic, or about the same as CFO's optimism. Of 453 CFOs who responded to this question, only $5.1 \%$ of the CFOs say they are more optimistic than their CEOs. The next question follows up and asks "Why do you think your CEO's optimism differs from yours?" We have 292 responses to this question from CFOs. The predominant response, $35.7 \%$ say that CEOs are more optimistic about almost everything i.e., CEOs are more optimistic about all aspects of life, above and beyond the CEO's extra optimism about business prospects. The results of this second survey deepen our earlier finding. Not only are CEOs more optimistic as per psychometric tests, they are also perceived to be more 
optimistic by their CFO colleagues. Taking these results together, this suggests that CEOs are indeed special in terms of their personality characteristics, in particular being more risk-tolerant as well as more optimistic than others.

We are able to use data that we collected from the survey to further compare a number of characteristics of CEOs to CFOs (see Table III, panel A). We first examine differences in U.S.CEOs and CFOs. It can be seen that CEOs are much less likely to have MBA degrees than are CFOs. CEOs are also likely to be older, and to have attended more prestigious universities. CEOs are less averse to sure losses and their main career path is less likely to be finance/accounting, relative to CFOs. CEOs tend to be more impatient than CFOs: there are a significantly larger proportion of CEOs with a high rate of time preference as compared to CFOs.

We need to be careful about drawing conclusions from these comparisons because they are unconditional, not having first matched the executives by firm characteristics. Hence, we recalculate the differences in characteristics of CEOs and CFOs after matching for whether the company is public or private. Panel A of Table III, column (2) shows that the results are similar when matching by public versus private status. We separately match by size in column (3). After matching we find similar results with the only exception being that the differences in time preference is no longer robustly significant. The results suggest that CEOs not only have different career paths from CFOs but importantly, differ in terms of their attitudes.

Next, we examine how U.S. CEOs and CFOs differ from executives from other parts of the world (panel B \& C in Table III). We find both CEOs and CFOs from the United States tend to 
be more risk tolerant than executives whose companies are not located in the United States. ${ }^{9}$ They are also more optimistic, and older.

Further, non-U.S. CEOs and CFOs tend to be less patient, as indicated by their higher rate of time preference, relative to their U.S. counterparts. Foreign CEOs also have a higher aversion to sure losses than U.S. CEOs. The only place that we find significant difference between U.S. and non-U.S. CEOs that does not hold in CFOs relates to educational background. U.S. CEOs are less likely to have a MBA than their non-U.S. counterparts, but U.S. CFOs are more likely to have a MBA than their non-U.S. counterpart

Again, we need to be careful in drawing conclusions since these comparisons are unconditional. Hence, we recalculate the differences in characteristics of U.S. CEOs to non-US CEOs after matching for whether the company is public or private. Panel B of Table III, column (2) shows that the results are similar when matching by public versus private status. We separately match by size in column (3). After matching we find the results that are robust to all three sampling methods are that U.S. CEOs are less risk averse, more optimistic and less averse to sure losses. The results suggest that U.S. CEOs tend to be very different in terms of their attitudes from non-U.S. CEOs.

We conduct a similar exercise in panel $\mathrm{C}$ of Table III where we examine the differences in U.S. CFOs as compared to non-U.S. CFOs matching in by private/public status and by size. We find similar to the difference in attitudes between U.S. CEOs and non-U.S. CEOs U.S. CFOs are less risk averse, more optimistic, and more patient than their non-U.S. counterparts. In addition U.S. CFOs are more likely to have a MBA degree

\footnotetext{
${ }^{9}$ U.S. CEOs and CFOs both tend to be taller (though this could be because of a native population height differential).
} 
In all, our results suggest that CEOs, particularly in the US, tend to possess certain personal traits, which may well be an integral part of having what it takes to become a CEO and/or to operate effectively as a chief executive. Our results suggest the importance of personality traits in occupational choice, an area where there has been relatively little evidence (an exception is Puri and Robinson, 2007, 2012). Further, the differences we find in U.S. CEOs and non-U.S. CEOs' attitudes may help explain why corporate objectives and behavior differ across countries, a subject of some debate (see e.g., Allen, 2005).

\subsection{Firm characteristics}

The summary statistics indicate that the median firm has two operating segments and has experienced median historical sales growth of $12 \%$. The median debt-to-assets ratio is $20 \%$, and the short-term debt to total debt ratio is $11 \% .{ }^{10}$ The mean (median) number of acquisitions over the past two years is $0.7(0)$. Performance sensitive compensation (stock, options, bonus) accounts for about $36 \%$ of the total compensation of the average executive in our sample, and salary accounts for about $57 \%$, with the rest composed of 'other' compensation. Note that our analysis is based primarily on self-reported survey data. Table 1, panel B reports the same information for public firms only. Since we have only 90 public firms the sample is somewhat sparse. As expected, the public companies are bigger with mean sales revenue of $\$ 2.37$ billion, 2.5 operating segments, median sales growth of $8.5 \%$ and median debt-to-assets ratio of $25 \%$. Performance sensitive compensation accounts for about $52 \%$ of compensation for these public

\footnotetext{
${ }^{10}$ We examine the data for internal consistency and typographical errors. As a result, one entry with negative debt/assets and two entries with short term debt ratio exceeding $100 \%$ are dropped; entries with fraction of debt ratio are changed to percentages; number of acquisitions at 100 (next highest is 26) are dropped (3 observations); and where the total of stock, option, bonus, salary and other compensation is outside the range of $90-110 \%$ of total compensation (15 observations), we treat these as missing.
} 
firms. Given that companies do not have to identify themselves in our survey, we cannot directly match all these 90 public firms with Compustat. Nonetheless, we do some benchmarking of our companies to the universe of companies in Compustat.

Table IV reports the correlations between both firm and executive characteristics for the U.S. CEOs. Some of the correlations are interesting, and some are intuitive. For example, older CEOs are less risk tolerant. CEOs with MBAs are younger and tend to have a career path in finance or accounting. As might be expected, older CEOs tend to work in larger firms, the prestige of the college from which they graduate matters less, and they are more likely to be male.

We also look at whether there are differences in the way CEOs of private firms are compensated as compared to CEOs of public firms. Breaking down our data, we observe that CEOs of private firms obtain, on average, $58.8 \%$ of their compensation from salary, as compared to $44.6 \%$ received by CEOs of public firms. In general, though, CEOs of private firms have a larger equity stake in their firm. In response to the question, "if all options were vested and exercised, what percent of your company's common stock would you own (e.g., 5\%)", CEOs of private firms have an average ownership of $38.1 \%$ as compared to $5.4 \%$ held by CEOs of public firms.

Following the recommendation by List (2007), we benchmark to Compustat, a frequently used database for corporate finance research. We examine sales, debt-to-assets, and other variables as shown in Appendix A1. Briefly, our sales comparison indicates that our sample firms are smaller than the typical Compustat firm, with two-fifths of our sample falling in the smallest Compustat quintile. This is not surprising given that $88.5 \%$ of our sample is comprised 
of private firms, while Compustat only contains public firms. When we restrict the comparison to public firms in our sample only (see Appendix A.2), the size discrepancy is less marked, with only $11.4 \%$ of sample firms falling in the smallest Compustat quintile. With this subset, $58.2 \%$ of our publicly listed sample firms fall within the third and fourth largest Compustat quintile. The survey response sample is fairly representative of the Compustat universe in terms of debt/assets, debt maturity, and historical growth.

We also check the self-reported responses of companies against the actual entries in Compustat for the firms that we can identify. There are 64 Compustat firms that we can identify in our data with self-reported leverage ratio. We find that the average self-reported debt/asset ratio for publicly listed firms was $24.4 \%$ with a standard deviation of 22.8. Average Computstat total debt/asset ratio for the same set of firms is $28.2 \%$ with a standard deviation of 26.7 . The mean difference (self reported minus Compustat debt ratio) is $-3.8 \%$, with a t-stat of -1.00 . Therefore, the difference between self reported and Compustat debt ratios is not statistically significant. $^{11}$

\subsection{Are CEO traits related to corporate decisions?}

We now study the traits of managers and whether they relate to corporate actions. We also analyze how managers' traits correlate with the compensation packages that they receive.

\footnotetext{
${ }^{11}$ We also check for the same company for which both the CEO and CFO respond whether they give the same response for "how many material acquisitions have you had in the last 2 years?" There were two companies in the database where we had both CEO and CFOs responding. For both of these companies, both the CEO and CFO report zero acquisitions.
} 
We first investigate whether CEO characteristics are associated with capital structure choices. Table V, Panel A examines univariate correlations between capital structure and CEO traits as well as company characteristics. In terms of what is related to the debt ratio (total debt/total assets), in the univariate comparisons the only significant characteristics are the past career path of the CEO and whether the CEO is male. If the CEO's past experience is primarily in the finance/accounting arena, then the firm uses significantly more total debt. In particular, of the CEOs who have prior experience in finance/accounting, 52\% lead companies that have a high debt ratio (i.e., above the sample mean). Of the CEOs with nonfinancial background, only $37 \%$ leade in companies with a high debt ratio.

Next, we examine debt maturity. As can be seen in the univariate analysis in Table V, panel A, males, optimists, and executives from private companies are more likely to use a higher proportion of short term debt. Theories such as Landier and Thesmar's (2009) suggest that optimists are more likely to take on short term debt. Our results are consistent with this implication and the optimism effect is highly significant. Similarly, if the male gender corresponds to being overconfident (Barber and Odean, 2001), the relation we find between short term debt and gender is consistent with overconfidence leading to more short-term debt usage.

We next examine debt ratios and debt maturity in a multivariate setting (see Table V, panel B). In the regressions, we include executive behavioral characteristics as well as controls for demographic and career related variables. We also include firm controls for size and public/private as well as industry controls, as these can potentially affect leverage choices. The results are similar to those seen in the univariate analysis, though the significance is not always as strong. In particular, the multivariate regressions show that behavioral characteristics matter for total debt as well as debt maturity. We find debt maturity is significantly related to optimism, 
after controlling for other factors. As can be seen in column (2), Table V, panel B, optimism is highly significant at 5\%. The results suggest that if a firm has a highly optimistic CEOs it is likely to have more debt, in particular more short-term debt; the increased marginal impact of a very optimistic CEO on short term debt ratio is $3.6 \%$.

CEO traits have often been thought to be important in merger and acquisition activity. CEOs themselves claim to be the dominant decision-maker in M\&A decisions (Graham et al., 2012. Accordingly, we first examine whether the number of acquisitions made by a company is related to managerial characteristics. There is a large literature characterizing the effects of acquisitions, but much of this literature pertains to public companies, whereas our sample consists largely of private companies. It is not necessary that the motivation for public companies is the same as that for private companies. Table $\mathrm{V}$, panel A examines whether a company makes any acquisitions over the previous two years. The univariate analysis suggests that CEOs who are more risk tolerant are more likely to make acquisitions. In addition we find that large firms and public firms are more likely to make such acquisitions, which is intuitive. We also find that when the CEO displays aversion to sure losses, then s/he is more likely to make acquisitions.

Table V, panel B, column (3) presents the results of a logit analysis in which the dependent variable equals 1 if the company makes any acquisitions and 0 otherwise. Among the behavioral characteristics, we find that the effect of the CEO's personal risk aversion is very significant. More risk tolerant CEOs are more likely to make acquisitions. ${ }^{12}$ From the coefficients in Table

\footnotetext{
12 The survey design allows us to test whether these results hold for the subset of CEOs who believe they are the dominant M\&A decision maker. For this purpose, we use the question "Amongst the management team, who has most of the input in mergers and acquisitions." The CEO is given a 7 point scale, where 1 represents "I make decision without help from others," 7 represents "others make decisions,' and the midpoint is "share decision equally with others." In unreported analysis we rerun our previous regressions
} 
$\mathrm{V}$, Panel B, the marginal effect is a $24.5 \%$ lower probability of making an acquisition for highly risk averse CEOs. This interesting result is consistent with the idea that CEO characteristics matter in acquisition activity, which has been theorized since Roll, 1986 (see also Malmendier and Tate, 2008).

We additionally perform an ordered logit analysis. Table V, panel B, column (4) presents the results when a single acquisition is made, and when multiple acquisitions are made. We also perform the regression using OLS and a continuous dependent variable: log of the number of acquisitions (Table V, panel B, column 5). Given our question asks whether CEOs have made any material acquisitions in the last two years, it makes sense to restrict our regressions to CEOs with at least 2 years tenure. Very few CEOs in our sample have tenure of less than two years. The number of observations for the full sample is 545 compared to 509 for CEOs with at least two years tenure. We perform the regression for the full sample of CEOs as well as for those with at least two years of tenure and find very similar results. For brevity, we report only the results with $\mathrm{CEO}$ of greater than two years tenure in the tables. As can be seen from Table V, the ordered logit yields very similar results to the earlier tests. Risk-tolerant CEOs are more likely to undertake an acquisition. We find similar results in the OLS regression. Our main result is that CEOs who are more risk loving are more likely to make acquisitions, and a larger number of acquisitions.

Overall, our results suggest that capital structure actions, both total debt and debt maturity, as well as acquisition activity are associated with CEO traits and the kind of career experience that managers have had in the past.

using only the subset of CEOs who scored themselves highly on making the decisions by themselves. We find qualitatively similar results in this subsample. 


\subsection{CEO traits and firm growth}

Caution needs to be exercised when interpreting the results in Section 3.3 because of potential reverse causality. There are two kinds of issues. First, do traits persist over time or does previous performance affects traits. Given the cross-sectional nature of our data it is hard to address this directly, though to the extent possible we introduce controls for past performance (historical growth) in our regressions. More broadly, however, other studies have found that optimism, in particular, is a trait that persists across time within individuals. Landier and Thesmar (2008) use panel data on French entrepreneurs to document (among other things) that optimism persists over time. Similarly, Kaniel, Massey and Robinson (2010) report findings from LOT-R results taken among a sample of U.S. MBA students at two points in time: once at the beginning of the educational program and again towards the end of the two-year degree to document little change in LOT_R results over this time horizon. These and other studies suggest that at least a component of the psychological variables we measure is likely to be fixed (or changing very slowly) over time. A second issue is that we are unable to distinguish whether managers with particular characteristics take certain corporate actions from whether managers with such characteristics select (or, are selected into) companies with prevalent debt or acquisition activity. Our results are consistent with either explanation.

Table VI, panel A examines the historical annual sales growth, as well as the future annual sales growth as anticipated by the CEO. The univariate tests indicate that risk tolerant CEOs are more likely to work in companies with high historical and high expected growth. Further, young CEOs, tall "confident" chief executives, and CEOs who do not have finance/accounting backgrounds are more likely to work for high growth companies. The chief executives who 
work in firms with high historic growth are less likely to have attended prestigious colleges. CEOs with an MBA are more likely to work for companies with high anticipated growth. If we interpret height as a measure of confidence, our results are consistent with a matching story in which young, confident, risk-tolerant CEOs are more likely to work for high growth companies. Similar patterns hold for firms with high anticipated future growth. These intriguing results are generally consistent with these kinds of CEOs choosing to work for growth companies, or at least companies with potential for future growth.

Table VI, panel B, column 1, presents the results of a logit regression in which the dependent variable is 1 if the company has high expected future growth, and 0 otherwise. The estimates suggest that risk tolerant CEOs are more likely to be employed at growth companies; we find a marginal effect of a highly risk averse CEO is an $8 \%$ reduced probability of working in a growth company. Similar results are found when we examine a logit in which the dependent variable is 1 if the historical growth rates are high, and 0 otherwise. Once again, we find that risk tolerant CEOs are more likely to be in growth firms. These results are consistent with some selfselection or matching occurring between certain kinds of CEOs and certain kinds of companies. Of course, it is also possible that risk-tolerant CEOs drive high growth in their companies. Clearly, this would be an issue worth investigating in future research with a design that allows one to differentiate between matching and causation.

\subsection{CEO traits and compensation}

We next examine policies which impact the CEOs directly by affecting their wealth, in particular compensation. Standard agency theory, regardless of whether based on 
screening/adverse selection or moral hazard, predicts a fundamental trade-off between increasing incentives and risk, i.e., the more risk-averse the agent, the more costly it is to provide payperformance incentives. Despite this, there has been little direct evidence to support this prediction in empirical analysis (see e.g., Prendergast, 2002).

Accordingly, we investigate the target compensation of the CEO. In particular, we ask whether CEOs are likely to be paid with a larger proportional share from a fixed component, such as salary, or from a performance-based component such as stock, options and bonuses. Table VI, panel A presents univariate statistics. The results are striking. Risk takers are much more likely to be paid with proportionately more stock, options and bonuses and much less likely to be compensated via salary. The same holds for young, tall, and male CEOs. Executives who are impatient (with a high rate of time preference) receive proportionally more in salary. Executives from prestigious colleges, public firms, and from finance/accounting tracks receive relatively less of their compensation in the form of salary. As might be expected, executives in small firms receive proportionately more in salary, and less in the form of stocks, options and bonuses.

We next investigate whether these results hold in multivariate specifications. Table VI, panel B, columns 2 and 3 present the regression results. We include all the controls, including for firm size and industry. ${ }^{13}$ We also control for equity ownership. In this multivariate analysis, the two personal characteristics that are significant are risk-taking, and rate of time preference. The results suggest that risk-tolerant CEOs are more likely to receive proportionately larger remuneration via stock/bonus/options and less via salary. Coefficient estimates from column (ii)

\footnotetext{
${ }^{13}$ The regressions have a control for large firms but as a robustness check we rerun the regressions using ln(firm size). Our results for risk aversion are very similar though the significance of impatience reduces.
} 
shows the marginal effect of a highly risk averse CEO is a decrease of $22.3 \%$ of having a high proportion of stock options and bonuses in total compensation. Executives who display high levels of impatience, demanding a high return to defer gains, are much more likely to be compensated with a proportionately smaller stock/options/bonus component.

These results are intuitive and are consistent with executives who possess certain characteristics matching with companies that offer the kind of compensation packages they prefer. Whether executives choose their package or the company tailors it to the kind of individual they are trying to recruit, the evidence is consistent with some matching that focuses on certain managerial and firm characteristics. This is an important result for a number of reasons. First, in the context of the compensation literature, firms typically undertake costly incentive schemes to induce managers to take on risk. The cost of giving appropriate risk taking incentives is higher if the CEO is risk-averse (Ross, 2004). Our results are consistent with there being a match of CEO risk aversion to the compensation package in a way that might make the compensation incentive components less costly, by giving performance based pay to those CEOs who are more willing to take on risk. Second, standard contracting models predict that the amount of risk the CEO bears in the optimal contract and the expected wage payment depends on his or her risk aversion. While there is a large compensation literature examining the determinants of compensation structure, this literature has typically examined firm level variables, such as firm size and industry to explain compensation structure (see e.g., Murphy, 1999). Our results provide new evidence relating risk aversion of managers to compensation.

As mentioned above, there is scarce empirical evidence of a trade-off between incentives and risk in compensation contracts, despite the strong theoretical predictions (see e.g., Prendergast, 2002). In several studies, firms with higher volatility are even found to have higher 
pay-performance sensitivity, i.e., the opposite of the prediction from theory (see e.g., Core and Guay, 2002, or Kaplan and Stromberg, 2004). Our finding that risk aversion actually decreases pay-performance sensitivity is, to our knowledge, one of the first direct pieces of evidence in favor of this theory. In addition, our findings suggest that differences in time preferences are also important for explaining compensation patterns, which is consistent with standard agency theory but is a prediction that is largely ignored in the literature. Finally, our finding that CEOs are on average much less risk averse than the general population fits nicely within this framework. Risk-aversion makes incentive pay costly, and increases the participation constraint of the manager. As a result, firms would prefer to hire less risk-averse agents as managers, everything else equal.

We conduct several robustness tests to clarify interpretation of our results. For example, it is possible that certain kinds of CEOs, such as more optimistic CEOs, are more likely to respond to our survey. First, we conduct another survey in which we ask CFOs how they perceive CEOs (described in more detail in Section 3.3). CFOs overwhelmingly perceive CEOs to be more optimistic then themselves, consistent with what we find in psychometric tests of CEOs. Second, in other studies, e.g., Brav et al. (2005) there were two samples - a conference participant (inperson) sample with a high response rate, and an Internet survey with a typical, lower response rate. Both samples show very similar results, suggesting that selection bias is not a dominant issue in surveys such as ours. Further, while we find CEOs are generally more optimistic, within the sample we have a lot of cross-sectional variation in corporate policies and behavioral characteristics of CEOs which we exploit in our tests. Finally, we have variables such as past growth as a control variable in the capital structure, acquisitions and compensation regressions. 
This does not alter our results for the behavioral variables, in particular, for optimism and riskaversion are robust.

\section{Conclusions}

We examine how U.S. CEOs differ from the lay population, CFOs, and non-U.S. chief executives. We assemble a unique database on sitting business executives in which we assess managers' personality traits and attitudes using well established methods that have been validated in psychology and experimental economics as providing a good gauge of peoples' attitudes. Our psychometric survey not only quantifies behavioral traits of senior managers but also gathers information related to the career path, education, and demographic characteristics of the managers.

We offer evidence that CEOs differ from both the lay population and CFOs. Interestingly, U.S. based CEOs also differ in significant ways from their non-U.S. counterparts, both in terms of career paths and attitudes, tending to be more optimistic and less risk-averse, among other things. These differences in attitudes suggest one possible explanation for why U.S. firms behave in some ways quite differently from non-U.S. firms.

We focus on the two corporate decisions that CEOs feel they have the most control overacquisitions and capital structure. We find evidence that links psychological traits such as risk aversion and optimism to corporate policies, in ways advocated by some theories. For example, more risk-tolerant CEOs make more acquisitions and more optimistic CEOs use more short-term debt. 
We also find an empirical link between managerial traits such as risk aversion with compensation structure, and pay-performance sensitivity. This result is consistent with the theoretical work from standard agency theory but direct evidence on this has been scarce. We also find that managerial impatience and time preference also affects their compensation structure in a way that might be expected by theory but which has received little attention. Our results provide new evidence of a role for specific behavioral traits, in particular risk-aversion and time-preference in the determination of compensation structure. 


\section{References}

Agarwal, S., J. Driscoll, X. Gabaix, and D. Laibson, 2009, The Age of Reason: Financial Decisions over the Life Cycle with Implications for Regulation. Brookings Papers on Economic Activity, Vol. Fall, pp. 51-117

Akerlof, G. A., 2006, The Missing Motivation in Macroeconomics, (Presidential Address, American Economic Association Meetings, 2007), Working paper, University of California, Berkeley.

Allen, F., 2005, Corporate Governance in Emerging Economics, Oxford Review of Economic Policy, 21(2), 164-177.

Andrade, G., M. Mitchell, and E. Stafford, 2001, New Evidence and Perspectives on Mergers, Journal of Economic Perspectives, 103-120.

Bailey, M. N., C. Huten and D. Campbell, 1992, Productivity Dynamics in Manufacturing Plants," Brookings Papers on Economic Activity: Microeconomics, 187-249.

Barber, B., and T. Odean, 2001, Boys will be Boys: Gender, Overconfidence, and Common Stock Investment, Quarterly Journal of Economics, 116 (1), 261-292.

Barsky, R. B., M. S. Kimball, F. T. Juster, and M. D. Shapiro, 1997, Preference parameters and behavioral heterogeneity: An experimental approach in the health and retirement survey, Quarterly Journal of Economics, 112 (2), 537-579.

Bertrand, M., and A. Schoar, 2003, Managing with Style: The Effect of Managers on Corporate Policy, joint with Marianne Bertrand, Quarterly Journal of Economics, 118 (4), 1169-1208.

Brav, A., J. Graham, C. Harvey and R. Michaely 2005, Payout Policy in the 21st Century, Journal of Financial Economics 77, 483 - 527

Case, A., and C. Pacson, 2008, Stature and status: Height, ability and labor market outcomes, Journal of Political Economy, 116 (3), 499-532.

Caves, R. E., 1998, Industrial Organization and New Findings on the Turnover and Mobility of Firms, Journal of Economic Literature, 36, 1947-1982.

Core, J.E., and W.R. Guay, 2002, The Other Side of the Trade-Off: The Impact of Risk on Executive Compensation: A Revised Comment, Working paper, Wharton School.

Chevalier, J., and G. Ellison, 1999, Are Some Mutual Fund Managers Better than Others? Cross-Sectional Patterns in Behavior and Performance, Journal of Finance, 875-899.

Deaton, A.S., and R. Arora, 2009, Life at the top: The benefits of height, NBER working paper. 
Frank, M. Z. and V. K. Goyal, 2007, Corporate Leverage: How Much Do Managers Really Matter?, Working Paper, Hong Kong University of Science and Technology and University of Minnesota.

Frederick, S., 2005, Cognitive reflection and decision making, Journal of Economic Perspectives, 19, 4, 25-42.

Graham, J. R., and C. R. Harvey, 2007, March Global CFO Outlook, http://www.cfosurvey.org .

Graham, J. R., and C.R. Harvey, 2001, The Theory and Practice of Corporate Finance:

Evidence from the Field. Journal of Financial Economics 60, 187-243.

Graham, J. R., C.R. Harvey and S. Rajgopal, 2005, The Economic Implications of Corporate Financial Reporting, Journal of Accounting and Economics 40, 3-73.

Graham, J. R., C. R. Harvey, and M. Puri, 2012, Capital Allocation and Delegation of Decision-Making Authority within Firms, Working paper, Duke University.

Heaton, J. B., 2002, Managerial Optimism and Corporate Finance, Financial Management, 31(2), 33-45.

Hackbarth, D., 2007, Managerial Traits and Capital Structure Decisions, Working paper, University of Washington, St. Louis.

Kaplan, S.N., M.M. Klebanov, and M. Sorensen, 2010, Which CEO characteristics and abilities matter? Journal of Finance, forthcoming.

Kaplan, S. N. and P. Stromberg, 2004, Characteristics, Contracts, and Actions: Evidence from Venture Capitalist Analyses. Journal of Finance, 59: 2177-2210.

Kaniel, R., C. Massey, D. Robinson, 2010, The Importance of Being an Optimist: Evidence from Labor Markets, NBER Working Paper 16328

Klepper, S., 2002, Firm Survival and the Evolution of Oligopoly, Rand Journal of Economics, 33(1), 37-61.

Landier, A., and D. Thesmar, 2009, Contracting with Optimistic Entrepreneurs: Theory and Evidence, Review of Financial Studies, 22(1), 117-150.

Lazear, E. P., 1995, Corporate Culture and the Diffusion of Values, in Horst Siebert, ed., Trends in Business Organization, Tubingen, Germany, J.C.B. Mohr (Paul Siebeck).

Lemmon, M., M. Roberts, and J. Zender, 2008, Back to the Beginning: Persistence and the Cross-Section of Corporate Capital Structure, Journal of Finance, 63, 1-37.

List, J. A., 2007, Field Experiments: A Bridge between Lab and Naturally-Occurring Data, NBER Working Paper. 
Loewenstein, G., Read, D., \& Baumeister, R.F., 2003, Time and Decision: Economic and Psychological Perspectives on Intertemporal Choice. New York: Russell Sage Foundation Press.

Malmendier, U., and G. Tate, 2005, CEO Overconfidence and Corporate Investment, Journal of Finance, 60 (6), 2661-2700.

Malmendier, U., and G. Tate, 2008, Who Makes Acquisitions? CEO Overconfidence and the Market's Reaction, Journal of Financial Economics, 2008, 89(1), 20-43.

Murphy, K. J., 1999, Executive Compensation, in Ashenfelter, O., Card, D. (Ed.), Handbook of Labor Economics Elsevier Science North Holland.

Persicao, N., A. Postlewaite, and D. Silverman, 2004, The Effect of Adolescent Experience on Labor Market Outcomes: The Case of Height, Journal of Political Economy, 112(5), 1019-1053.

Prendergast, C., 2002, The tenuous tradeoff between risk and incentives, Journal of Political Economy, 110(5), 1071-1102.

Puri, M., and D. Robinson, 2007, Optimism and Economic Choice, Journal of Financial Economics, 86, 71-99.

Puri, M., and D. Robinson, 2012, The economic psychology of entrepreneurship and family business, Journal of Economics \& Management Strategy, forthcoming.

Roll, R., 1986, The Hubris Hypothesis of Corporate Takeovers, Journal of Business, 59 (2), 197-216.

Ross, S., 2004, Compensation, Incentives, and the Duality of Risk Aversion and Riskiness, Journal of Finance, 59(1), 207-225.

Scheier, M. F., Carver, C. S., and M. W. Bridges, 1994, Distinguishing optimism from neuroticism (and trait anxiety, self-mastery, and self-esteem): A re-evaluation of the Life Orientation Test, Journal of Personality and Social Psychology, 67, 1063-1078.

Shefrin, H., 2005, A Behavioral Approach to Asset Pricing, Academic Press Advanced Finance Series.

Slemrod, J., and V, Varsha, 2002, The Income Tax Compliance Cost of Large and Mid-Size Businesses (September 2002). Ross School of Business Paper No. 914.

Trahan, E.A. and L.J. Gitman, 1995, "Bridging the Theory-Practice Gap in Corporate Finance. A Survey of Chief Financial Officers." Quarterly Review of Economics and Finance 35, 73-87.

Van den Steen, E., 2005, Organizational Beliefs and Managerial Values, Journal of Law, Economics, and Organization, 21, 256-283. 


\section{TABLE I}

FIRM CHARACTERISTICS SUMMARY STATISTICS. This table reports the summary statistics of specific firm characteristics used in the analysis. All variables reflect the survey responses of participating U.S. CEOs. Firm sales (size) is determined based a survey question categorizing firm sales into seven size groups. Category midpoints are used to create the firm size variable reported here. Category 1 includes firms with sales less than $\$ 25 \mathrm{M}$, category 2 includes firms with sales between $\$ 25 \mathrm{M}$ and $\$ 99 \mathrm{M}$, category 3 includes firms with sales between $\$ 100 \mathrm{M}$ and $\$ 499 \mathrm{M}$, category 4 includes firms with sales between $\$ 500 \mathrm{M}$ and $\$ 999 \mathrm{M}$, category 5 includes firms with sales between $\$ 1 \mathrm{~B}$ and $\$ 4.9 \mathrm{~B}$, category 6 includes firms with sales between $\$ 5 \mathrm{~B}$ and $\$ 9.9 \mathrm{~B}$, and category 7 includes firms with $\$ 10 \mathrm{~B}$ or above in sales. Historical and expected growth reflect growth in sales. Number of operating segments refer to the number of segments in which the reporting executive has experience in prior to current position. Number of acquisitions reflects the number of acquisitions the firm has made over the past two years. Executive compensation variables (stocks, options, bonuses, and salary) are percentages of total compensation.

Panel A: All Firms

Public (\%)

Sales (Size) Revenue (\$M)

\# Operating Segments

Historical Growth (\%)

Expected Growth $(\%)$

Debt to Assets Ratio (\%)

Short Term Debt to Total Debt Ratio (\%)

Number of Acquisitions

Stocks, Options, and Bonuses (\%)

Salary (\%)

Stock Ownership (\%)

\begin{tabular}{cccccc} 
Observations & Mean & Std. Dev. & Minimum & Median & Maximum \\
\hline 785 & 11.5 & N/A & N/A & N/A & N/A \\
961 & 551.0 & $1,819.3$ & 12.5 & 62 & 12,500 \\
1,001 & 2.2 & 1.4 & 1.0 & 2 & 12 \\
948 & 22.2 & 45.4 & -30.0 & 12 & 500 \\
952 & 18.6 & 19.2 & -5.0 & 12 & 99
\end{tabular}

Panel B: Public Firms only

Public (\%)

Sales (Size) Revenue (\$M)

\# Operating Segments

Historical Growth (\%)

Expected Growth (\%)

Debt to Assets Ratio (\%)

Short Term Debt to Total Debt Ratio (\%)

Number of Acquisitions

Stocks, Options, and Bonuses (\%)

Salary (\%)

$\begin{array}{lccccc}811 & 26.6 & 25.2 & 0.0 & 20 & 100 \\ 805 & 25.0 & 29.6 & 0.0 & 11 & 100 \\ 872 & 0.7 & 1.5 & 0.0 & 0 & 9 \\ 793 & 36.7 \% & 26.2 \% & 0.0 \% & 35.0 \% & 100.00 \% \\ 795 & 57.1 \% & 26.4 \% & 0.0 \% & 60.0 \% & 100.00 \% \\ 788 & 33.9 \% & 36.5 \% & 0.0 \% & 17.5 \% & 100.0 \%\end{array}$

Stock Ownership (\%)

\begin{tabular}{cccccc} 
Observations & Mean & Std. Dev. & Minimum & Median & Maximum \\
\hline 90 & $100.0 \%$ & N/A & N/A & N/A & N/A \\
90 & $2,378.6$ & $3,810.4$ & 12.5 & 299.5 & $12,500.0$ \\
88 & 2.5 & 1.3 & 1.0 & 3 & 6 \\
90 & $15.2 \%$ & $18.9 \%$ & $-10.0 \%$ & $8.5 \%$ & $125 \%$ \\
90 & $13.5 \%$ & $12.5 \%$ & $1.0 \%$ & $10 \%$ & $75 \%$ \\
79 & & & & & \\
79 & $28.3 \%$ & $26.1 \%$ & 0.0 & $25.0 \%$ & $100.0 \%$ \\
88 & $20.5 \%$ & $25.5 \%$ & 0.0 & $10.0 \%$ & $100.0 \%$ \\
87 & 1.2 & 1.6 & 0.0 & 1.0 & 9 \\
87 & $52.4 \%$ & $23.3 \%$ & $0.0 \%$ & $55.0 \%$ & $98.0 \%$ \\
88 & $44.6 \%$ & $22.9 \%$ & $0.0 \%$ & $40.0 \%$ & $100.0 \%$ \\
& $5.4 \%$ & $14.80 \%$ & $0.0 \%$ & $1.0 \%$ & $100.0 \%$ \\
\hline
\end{tabular}


TABLE II

PERSONAL CHARACTERISTICS OF CORPORATE EXECUTIVES. Panel A reports the summary statistics of personal characteristics of U.S. CEOs. Highly risk averse is a dummy variable for executives that prefer a job that pays with certainty their current salary against jobs that pay twice their current income with $50 \%$ chance and $80 \%$ of their current income with $50 \%$ chance. MBA degree is a dummy variable for executives with MBA degrees. Very optimistic is a dummy variable for an executive that has reported an average of 4 or higher in the LOT-R Test. Averse to sure losses is a dummy for executives who avoids sure losses now by hedging. Focused in Fin. \& Acc. is a dummy for executives who have experience focused in financial and/or accounting fields. Tenure is the number of years the executive has been in current position. Impatient is a dummy variable for executives who prefer money now over money a year later at an interest of $30 \%$. Stock Ownership measures the fraction of a firm's stock that the executive will own if all stock options are exercised.

\begin{tabular}{|c|c|c|c|c|c|c|}
\hline Panel A: Summary Statistics & Observations & Mean & Std. Dev. & Minimum & Median & Maximum \\
\hline Highly risk averse (\%) & 1,008 & 9.8 & 29.8 & 0 & 0 & 100 \\
\hline MBA Degree (\%) & 916 & 34.9 & 47.7 & 0 & 0 & 100 \\
\hline Male (\%) & 1,009 & 92.3 & 26.7 & 0 & 100 & 100 \\
\hline Male Height (inches) & 881 & 71.2 & 2.8 & 52 & 71 & 82 \\
\hline Female Height (inches) & 78 & 65.7 & 2.4 & 58 & 66 & 71 \\
\hline Very Optimistic (\%) & 992 & 80.2 & 39.8 & 0 & 100 & 100 \\
\hline Averse to sure losses (\%) & 861 & 8.5 & 27.9 & 0 & 0 & 100 \\
\hline Impatient (\%) & 996 & 32.9 & 47.0 & 0 & 0 & 100 \\
\hline Focused in Fin. \& Acc. (\%) & 986 & 16.0 & 36.7 & 0 & 0 & 100 \\
\hline Age & 992 & 54.1 & 9.4 & 25 & 54 & 89 \\
\hline University SAT Score & 842 & $1,159.8$ & 156.6 & 750 & 1,140 & 1,485 \\
\hline Tenure & 1,011 & 10.4 & 8.4 & 0.5 & 8 & 56 \\
\hline Stock Ownership (\%) & 788 & 33.9 & 36.5 & 0 & 17.5 & 100 \\
\hline
\end{tabular}


TABLE III: COMPARISONS OF EXECUTIVE CHARACTERISTICS ACROSS SAMPLES. This table reports the summary statistics of specific personal characteritics of participating executives used in the analysisPanel A - C compares the characteristics of US CEOs against those of U.S. CFOs, U.S. CEOs with Non-U.S. CEOs and U.S. CFOs with Non-US CFOs respectively based on three sampling methods. The first, unconditional, uses the entire sample. The second sampling method matches firms one-on-one based on public/private status, randomly sampling when the number of sampling methods. The first, unconditional, uses the entire sample. The second sampling method matches firms one-on-one based on public/private status, randomly sampling when the number of
observations are uneven. The third sample method matches firms one-on-one based on size categories. Panel A compares U.S. CEOs to U.S. CFOs using the 3 sampling methods described above, while observations are uneven. The third sample method matches firms one-on-one based on size categories. Panel A compares U.S. CEOs to U.S. CFOs using the 3 sampling methods described above, while
Panel B compares the characteristics of US CEOs against those of non-US CEOs in the same way. Panel C compares the characteristics of U.S. CFOs against those of non-U.S. CFOs for the three sampling methods. Variables are defined as in Table II. Summary statistics reflects means where applicable. Significance at the $10 \%$ level is denoted by *, $5 \%$ by $* *$, and $1 \%$ by $* * *$. Number of observations are included in the panel header.

Panel A: Comparisons between US CEOs and US CFOs based on three sampling methods

\begin{tabular}{|c|c|c|c|c|c|c|c|c|}
\hline & \multicolumn{2}{|c|}{ (1) Unconditional 1011 CEOs / 534 CFOs } & \multicolumn{3}{|c|}{ (2) Public/Private Matching 383} & \multicolumn{3}{|c|}{ (3) Size Matching 417} \\
\hline & US CEOs vs & US CFOs & US CEOs & vs & US CFOs & US CEOs & vs & US CFOs \\
\hline Highly risk averse (\%) & 9.8 & 8.4 & 10.8 & & $7.0 *$ & 10.6 & & 8.7 \\
\hline MBA Degree (\%) & 34.9 & $51.8 * * *$ & 34.1 & & $49.3 * * *$ & 32.8 & & $49.5 * * *$ \\
\hline Male (\%) & 92.3 & 90.4 & 93.7 & & 93.0 & 95.7 & & $90.1 * * *$ \\
\hline Male Height (inches) & 71.2 & 71.0 & 71.1 & & 70.9 & 71.2 & & 70.9 \\
\hline Female Height (inches) & 65.7 & 65.1 & 66.2 & & $64.5 * *$ & 66.4 & & $64.7 * *$ \\
\hline Very Optimistic (\%) & 80.2 & $65.3 * * *$ & 83.5 & & $65.7 * * *$ & 79.7 & & $66.3 * * *$ \\
\hline Averse to sure losses (\%) & $8.5 \%$ & $13.2 * * *$ & 8.8 & & 11.7 & $7.8 \%$ & & $11.6 *$ \\
\hline Impatient (\%) & 32.8 & $26.4 * * *$ & 30.4 & & $24.9 *$ & 28.0 & & 26.8 \\
\hline Focused in Fin. \& Acc. (\%) & 15.6 & $86.7 * * *$ & 15.9 & & $85.2 * * *$ & 16.8 & & $87.7 * * *$ \\
\hline Age & 54.1 & $48.6 * * *$ & 54.0 & & $49.0 * * *$ & 55.0 & & $48.7 * * *$ \\
\hline University SAT Score & 1159.8 & $1113.5 * * *$ & 1165.8 & & $1109.0 * * *$ & 1145.2 & & $1106.3 * * *$ \\
\hline Tenure (Years) & 10.4 & $6.8 * * *$ & 9.9 & & $7.1 * * *$ & 10.3 & & $6.9 * * *$ \\
\hline Stock Ownership (\%) & 33.9 & $3.8 * * *$ & 28.7 & & $4.5 * * *$ & 20.0 & & $3.8 * * *$ \\
\hline
\end{tabular}

Panel B: Comparisons between US CEOs and Non-US CEOs based on three sampling methods

\begin{tabular}{|c|c|c|c|c|c|c|c|c|}
\hline & \multicolumn{2}{|c|}{ (1) Unconditional 1011 US / 162 Non-US } & \multicolumn{3}{|c|}{ (2) Public/Private Matching 120} & \multicolumn{3}{|c|}{ (3) Size Matching 153 } \\
\hline & US CEOs vs & Non-US CEOs & US CEOs & vs & Non-US CEOs & US CEOs & vs & Non-US CEOs \\
\hline Highly risk averse (\%) & 9.8 & $16.7 * * *$ & 5.8 & & $17.6^{* * *}$ & 9.2 & & $17.1^{* *}$ \\
\hline MBA Degree $(\%)$ & 34.9 & $48.2 * * *$ & 33.9 & & $51.9 * * *$ & 39.9 & & 48.9 \\
\hline Male $(\%)$ & 92.3 & 94.4 & 92.5 & & 95.0 & 94.7 & & 94.7 \\
\hline Male Height (inches) & 71.2 & $69.3 * * *$ & 70.9 & & $69.7 * * *$ & 71.1 & & $69.2^{* * *}$ \\
\hline Female Height (inches) & 65.7 & $56.9 * * *$ & 67.1 & & 53.1 & 66.8 & & 55.7 \\
\hline Very Optimistic (\%) & 80.2 & $54.1 * * *$ & 80.7 & & $57.6^{* * *}$ & 78.7 & & $53.1^{* * *}$ \\
\hline Averse to sure losses $(\%)$ & 8.5 & $19.7 * * *$ & 4.3 & & $17.9^{* * *}$ & 8.6 & & $19.7^{* * *}$ \\
\hline Impatient (\%) & 32.8 & $41.4 * *$ & 28.3 & & $38.7^{*}$ & 36.2 & & 41.1 \\
\hline Focused in Fin. \& Acc. (\%) & 15.6 & $25.3 * * *$ & 18.3 & & 26.9 & 19.0 & & 25.0 \\
\hline Age & 54.1 & $50.0 * * *$ & 54.9 & & $49.7 * * *$ & 52.9 & & $49.7 * *$ \\
\hline University SAT Score & 1159.8 & 1208.7 & 1154.2 & & 1189.6 & 1157.5 & & 1201.5 \\
\hline Tenure (Years) & 10.4 & $9.0^{*}$ & 10.0 & & $8.0^{*}$ & 10.3 & & $8.5^{*}$ \\
\hline Stock Ownership (\%) & 33.9 & 33.6 & 31.7 & & 33.4 & 40.2 & & 33.6 \\
\hline
\end{tabular}


Panel C: Comparisons between US CFOs and Non-US CFOs based on three sampling methods

Highly risk averse (\%)

MBA Degree (\%)

Male (\%)

Male Height (inches)

Female Height (inches)

Very Optimistic (\%)

Averse to sure losses (\%)

Impatient (\%)

Focused in Fin. \& Acc. (\%)

Age

University SAT Score

Tenure (Years)

Stock Ownership (\%)

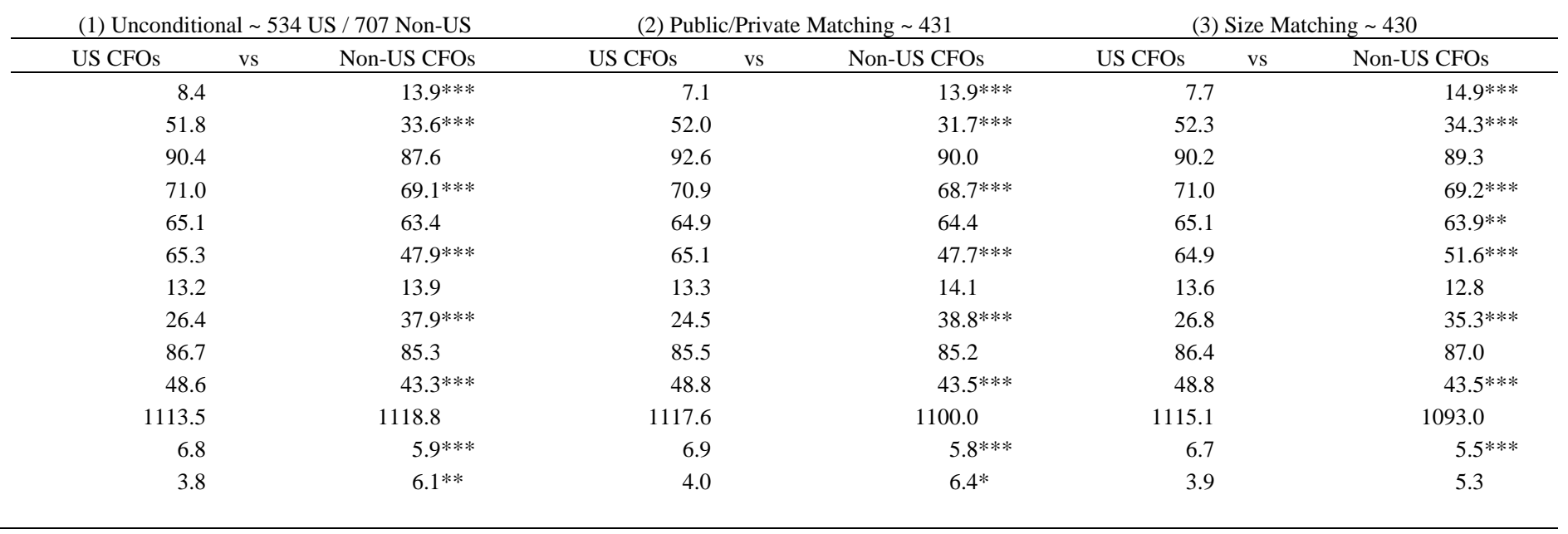




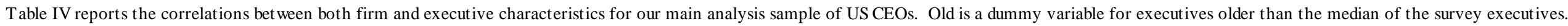

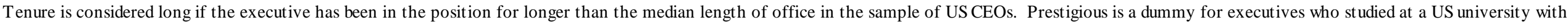

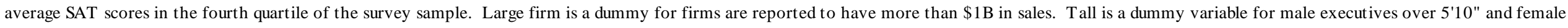
executives over $54^{\prime} 4$. Other variables are defined as in Table II. Significance at the $10 \%$ level is denoted by $*, 5 \%$ by $* *$, and $1 \%$ by $* * *$.

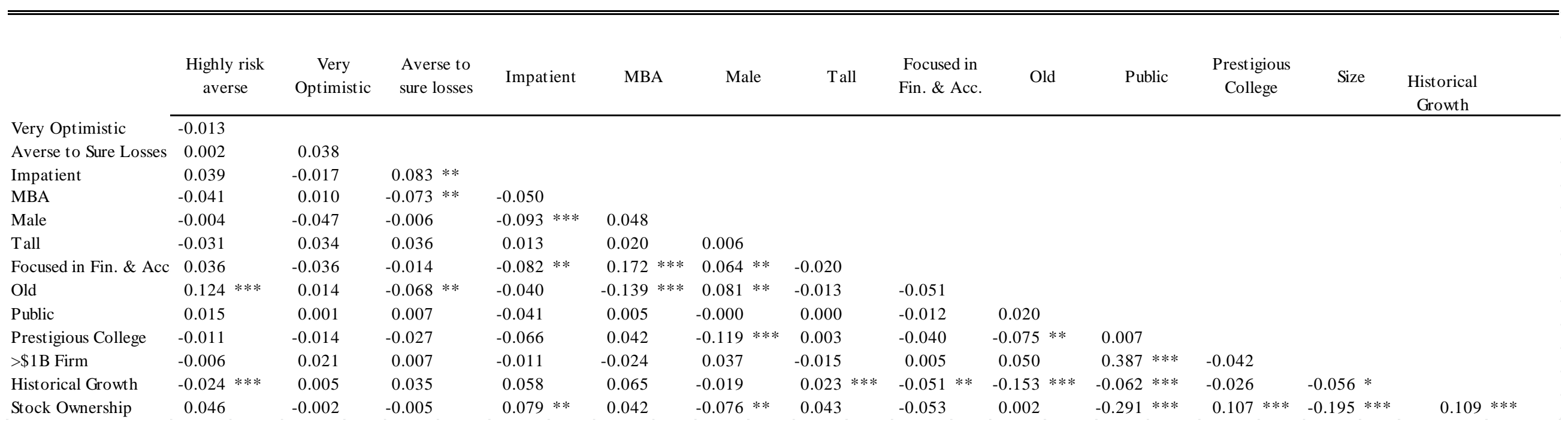


TABLE V A

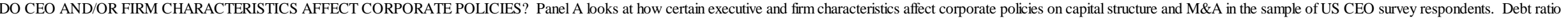

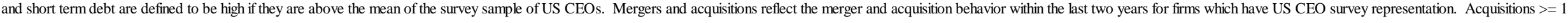

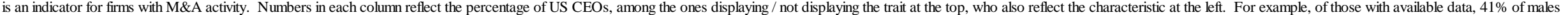

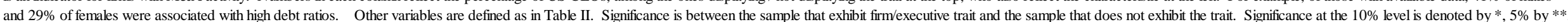
and $1 \%$ by $* * *$.

Panel A: Firm/executive traits and corporate policies

\begin{tabular}{|c|c|c|c|c|c|c|c|c|c|c|c|c|c|c|c|c|c|c|c|c|}
\hline \multirow{4}{*}{$\begin{array}{l}\text { High debt ratio } \\
\text { \# Observations }\end{array}$} & \multicolumn{2}{|c|}{$\begin{array}{l}\text { Highly risk } \\
\text { averse }\end{array}$} & \multicolumn{2}{|c|}{$\begin{array}{c}\text { Very } \\
\text { Optimistic }\end{array}$} & \multicolumn{2}{|c|}{$\begin{array}{c}\text { Averse to } \\
\text { Sure Losses }\end{array}$} & Impatient & MBA & \multirow{2}{*}{\multicolumn{2}{|c|}{$\begin{array}{c}\text { Gender } \\
\text { Male Female }\end{array}$}} & \multicolumn{3}{|c|}{$\begin{array}{l}\text { Fin / Acc } \\
\text { Focused }\end{array}$} & Old & \multicolumn{4}{|c|}{$\begin{array}{c}\text { Prestigious } \\
\text { College }\end{array}$} & \multicolumn{2}{|c|}{ Small Firm } \\
\hline & High & Low & Yes & No & Yes & No & Yes No & Yes No & & & Yes No & Yes & No & Yes No & Public & Private & Yes & No & Yes & No \\
\hline & 33 & 41 & 41 & 35 & 38 & 40 & $\begin{array}{ll}38 & 41\end{array}$ & $\begin{array}{ll}39 & 39\end{array}$ & 41 & $29 *$ & $39 \quad 42$ & 52 & $37 * * *$ & $39 \quad 40$ & 47 & 40 & 39 & 42 & 39 & $51 *$ \\
\hline & \multicolumn{2}{|c|}{808} & \multicolumn{2}{|c|}{797} & \multicolumn{2}{|c|}{794} & 808 & 735 & \multicolumn{2}{|c|}{809} & 806 & \multicolumn{2}{|c|}{796} & 809 & \multicolumn{2}{|c|}{713} & \multicolumn{2}{|c|}{682} & \multicolumn{2}{|c|}{809} \\
\hline High short term debt rat & 26 & 34 & 35 & $24 * * *$ & 28 & 33 & $34 \quad 33$ & $30 \quad 34$ & 34 & $17 * * *$ & $32 \quad 36$ & 36 & 32 & $35 \quad 30$ & 25 & $34 *$ & 29 & 35 & 33 & 28 \\
\hline \# Observations & 81 & & & & & & 802 & 731 & & & 801 & 79 & & 803 & & & 67 & & 803 & \\
\hline $\begin{array}{l}\text { Acquisition }=0 \\
\# \text { Observations }\end{array}$ & $\begin{array}{r}74 \\
86\end{array}$ & $65 *$ & $\begin{array}{r}65 \\
8 \\
\end{array}$ & $7^{66}$ & & $67 *$ & $\begin{array}{c}65 \quad 66 \\
869 \\
\end{array}$ & $\begin{array}{c}68 \quad 65 \\
790\end{array}$ & & 65 & $\begin{array}{c}66 \quad 65 \\
865 \\
\end{array}$ & $\begin{array}{r}70 \\
8\end{array}$ & 65 & $\begin{array}{c}66 \quad 66 \\
868 \\
\end{array}$ & $\begin{array}{r}47 \\
7\end{array}$ & $67 * * *$ & $\begin{array}{l}71 \\
72 \\
\end{array}$ & $65 *$ & $\begin{array}{l}68 \\
867 \\
\end{array}$ & $40 * * *$ \\
\hline $\begin{array}{l}\text { Acquisitions } \geq 1 \\
\text { \# Observations }\end{array}$ & 26 & $35 *$ & $\begin{array}{r}35 \\
8\end{array}$ & $7^{34}$ & $\begin{array}{r}44 \\
8\end{array}$ & $33 *$ & $\begin{array}{c}35 \quad 34 \\
869\end{array}$ & $\begin{array}{c}32 \quad 35 \\
790\end{array}$ & 34 & 35 & $\begin{array}{c}34 \quad 35 \\
865\end{array}$ & 30 & 55 & $\begin{array}{c}34 \quad 34 \\
868\end{array}$ & 53 & $33 * * *$ & $\begin{array}{l}29 \\
72\end{array}$ & $35 *$ & $\begin{array}{l}32 \\
867\end{array}$ & $60 * * *$ \\
\hline
\end{tabular}




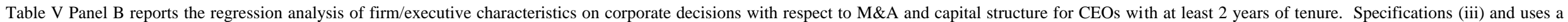

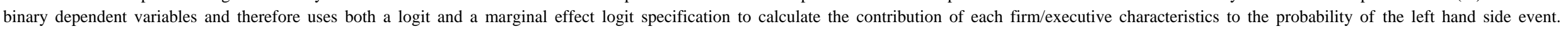

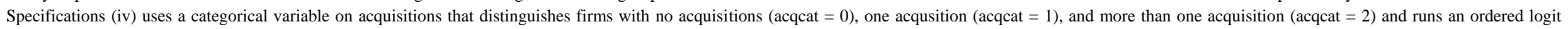

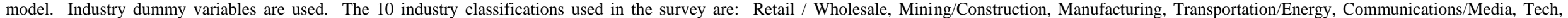

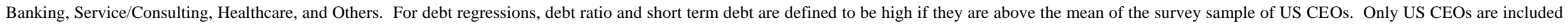

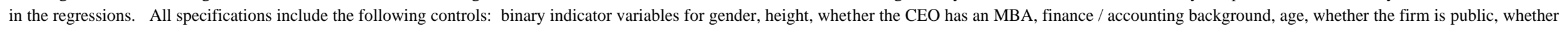

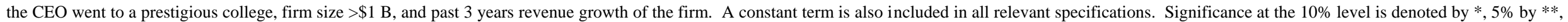
and $1 \%$ by $* * *$, with $\mathrm{z}$-stats reported in parenthesis.

\begin{tabular}{|c|c|c|c|c|c|c|c|}
\hline & \multicolumn{2}{|c|}{ OLS } & \multirow{2}{*}{\multicolumn{2}{|c|}{$\begin{array}{c}\text { Logit } \\
\text { (iii) }\end{array}$}} & \multirow{2}{*}{\multicolumn{2}{|c|}{$\begin{array}{l}\text { Ordered Logit } \\
\text { (iv) }\end{array}$}} & OLS \\
\hline & (i) & (ii) & & & & & $(\mathrm{v})$ \\
\hline & \multicolumn{2}{|c|}{ All CEOs for debt regressions } & \multicolumn{5}{|c|}{ CEO Tenure at least 2 years for acquisition regressions } \\
\hline & High Debt Ratio & $\begin{array}{l}\text { High Short Term Debt } \\
\text { Ratio }\end{array}$ & \multicolumn{2}{|c|}{ Made Acquisitions } & \multicolumn{2}{|c|}{$\begin{array}{l}\text { No Acquisitions vs. } 1 \text { Acquisition vs. more } \\
\text { than } 1 \text { Acquisition }\end{array}$} & $\operatorname{Ln}($ Acq +1$)$ \\
\hline & Coefficients & Coefficients & Coefficients & Marginal Effects & Coefficients & $\begin{array}{c}\text { Marginal Effects } \\
(\text { acqcat }=1 / \text { acqcat }=2)\end{array}$ & Coefficients \\
\hline \multirow[t]{2}{*}{ Highly risk averse } & 0.004 & -0.016 & $-1.108^{* *}$ & $-0.246^{* *}$ & $-1.160^{* *}$ & $-0.257 * * /-0.275 * *$ & $-0.168 * *$ \\
\hline & $(0.09)$ & $(0.69)$ & $(2.44)$ & $(2.46)$ & $(2.44)$ & & $(1.99)$ \\
\hline \multirow[t]{2}{*}{ Very Optimistic } & $0.049 *$ & $0.036^{* *}$ & 0.152 & 0.034 & 0.120 & $0.035 / 0.038$ & 0.027 \\
\hline & $(1.80)$ & $(2.36)$ & $(0.56)$ & $(0.56)$ & $(0.43)$ & & $(0.45)$ \\
\hline \multirow{2}{*}{$\begin{array}{l}\text { Averse to } \\
\text { sure losses }\end{array}$} & 0.043 & 0.045 & 0.386 & 0.085 & 0.591 & $0.089 / 0.096$ & 0.143 \\
\hline & (1.13) & $(1.39)$ & $(1.15)$ & $(1.15)$ & (1.63) & & $(1.56)$ \\
\hline Impatient & (1.10) & (1.14) & $(0.76)$ & $(0.76)$ & $(0.63)$ & & $(1.01)$ \\
\hline Control Variables & Yes & Yes & Yes & & Yes & & Yes \\
\hline Industry Dummies & Yes & Yes & Yes & & Yes & & Yes \\
\hline $\mathrm{N}$ & 507 & 503 & 504 & & 504 & & 504 \\
\hline $\begin{array}{l}\chi^{2}(\mathrm{df}) \text { for Logit / } \\
\text { R-squared for OLS }\end{array}$ & $11.94 \%$ & $7.26 \%$ & $39.82(21)$ & & $50.78(21)$ & & $13.05 \%$ \\
\hline P-Value & $<0.01$ & $<0.01$ & $<0.01$ & & $<0.01$ & & $<0.01$ \\
\hline Pseudo R-squared & $11.94 \%$ & $7.26 \%$ & $8.1 \%$ & & $7.30 \%$ & & $13.05 \%$ \\
\hline
\end{tabular}


TABLE VIA

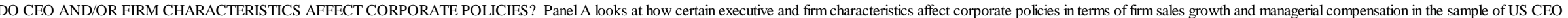

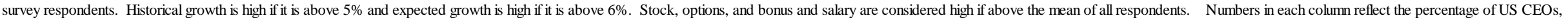

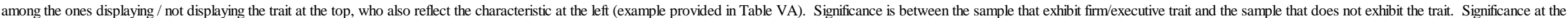
$10 \%$ level is denoted by $*, 5 \%$ by $* *$, and $1 \%$ by ***.

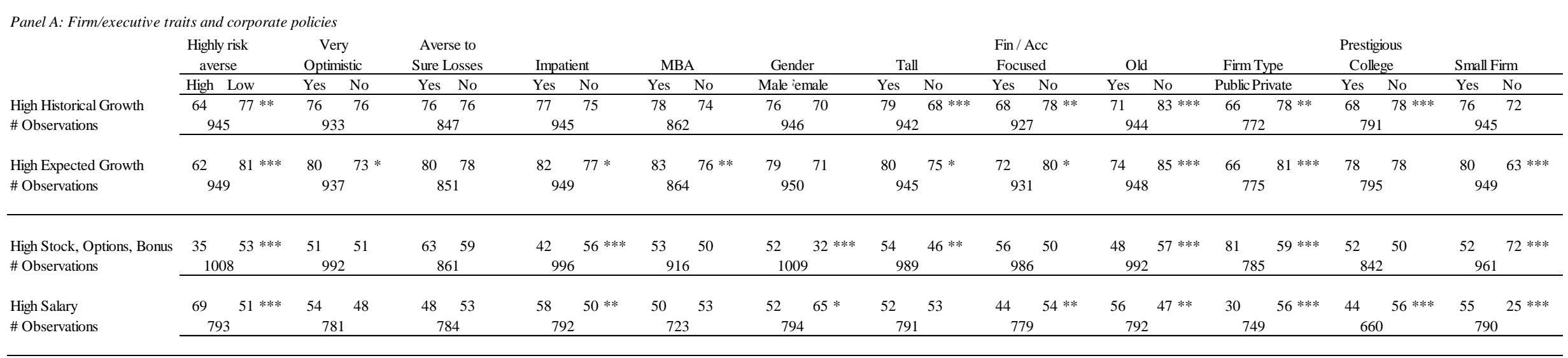




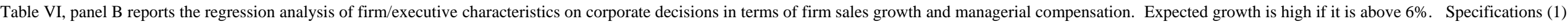

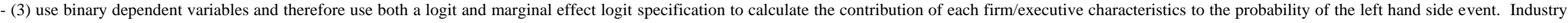

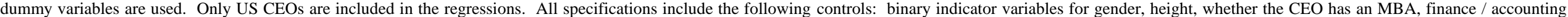

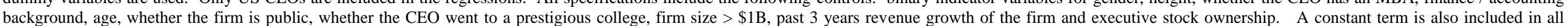
relevant specifications. Significance at the $10 \%$ level is denoted by $*, 5 \%$ by $* *$, and $1 \%$ by $* * *$, with z-stats and t-stats reported in parenthesis.

(ii)

High Expected Growth

\begin{tabular}{cr}
\hline & \\
Coefficients & Marginal \\
\hline$-0.834^{*}$ & -0.080 \\
$(1.96)$ & $(1.26)$ \\
& \\
0.421 & 0.040 \\
$(1.14)$ & $(1.02)$ \\
& \\
0.207 & 0.002 \\
$(0.45)$ & $(0.43)$ \\
& \\
0.282 & 0.003 \\
$(0.88)$ & $(0.83)$ \\
Yes & \\
Yes & \\
513.0 & \\
$112.3(22)$ & \\
$<0.01$ & \\
$39.5 \%$ &
\end{tabular}

High Stock, Options, and Bonus

High Salary
Marginal Effects

$\begin{array}{cc}\text { Coefficients } & \text { Marginal Effe } \\ -0.900 * * & -0.223 * * \\ (2.15) & (2.15) \\ & \\ 0.027 & 0.007 \\ (0.11) & (0.11) \\ & \\ 0.527 & 0.131 \\ (1.53) & (1.53) \\ -0.452 * * & -0.112 * * \\ (2.03) & (2.03)\end{array}$

Yes

Yes

506.0

$60.0(22)$

$<0.01$

$10.2 \%$

$\begin{array}{cc}\text { Coefficients } & \text { Marginal Effects } \\ 1.152 * * * & 0.287 * * * \\ (2.81) & (2.81) \\ & \\ 0.126 & 0.031 \\ (0.51) & (0.51) \\ & \\ -0.316 & -0.079 \\ (0.94) & (0.94) \\ & \\ 0.166 & 0.041 \\ (0.78) & (0.78) \\ & \\ \text { Yes } & \\ \text { Yes } & \\ 506.0 & \\ 40.9(22) & \\ <0.01 & \\ 7.05 \% & \end{array}$




\section{APPENDIX A1}

Comparison of the survey sample of the firms under management of US CEOs to the Compustat sample using survey variable definitions. The survey data is matched against the 2005 annual Compustat data for consistency as our survey is conducted in early 2006, which should reflect 2005 financials. Sales is surveyed by seven size categories. Category 1 includes firms with sales less than $\$ 25 \mathrm{M}$, category 2 includes firms with sales between $\$ 25 \mathrm{M}$ and $\$ 99 \mathrm{M}$, category 3 includes firms with sales between $\$ 100 \mathrm{M}$ and $\$ 499 \mathrm{M}$, category 4 includes firms with sales between $\$ 500 \mathrm{M}$ and $\$ 999 \mathrm{M}$, category 5 includes firms with sales between $\$ 1 \mathrm{~B}$ and $\$ 4.9 \mathrm{~B}$, category 6 includes firms with sales between $\$ 5 \mathrm{~B}$ and $\$ 9.9 \mathrm{~B}$, and category 7 includes firms with $\$ 10 \mathrm{~B}$ or above in sales. Debt to assets ratio, short term debt ratio, dividend yield, and historical growth are reported by US CEO survey respondent.

Credit rating is the $\mathrm{S} \& \mathrm{P}$ long term domestic issuer credit rating grouped into 10 categories in order of increasing credit ratings. Category 1 include firms with credit ratings of D or suspended, category 2 include firms with ratings of C, or CI, category 3 include firms with ratings of $\mathrm{CC}$, category 4 include firms with ratings of $\mathrm{CCC}-, \mathrm{CCC}$, or $\mathrm{CCC}+$, category 5 include firms with ratings of $\mathrm{B}-, \mathrm{B}$, or $\mathrm{B}+$, category 6 include firms with ratings of $\mathrm{BB}-, \mathrm{BB}$, or $\mathrm{BB}+$, category 7 include firms with ratings of $\mathrm{BBB}-, \mathrm{BBB}$, or $\mathrm{BBB}+$, category 8 include firms with ratings of $\mathrm{A}-$, A, or A+, category 9 include firms with ratings of AA-, $\mathrm{AA}$, or $\mathrm{AA}+$, and category 10 include firms with ratings of AAA-, or AAA.

Compare to Compustat Using Survey Variable Definitions

\begin{tabular}{|c|c|c|c|c|c|c|c|c|}
\hline \multirow[b]{2}{*}{ Variable } & & \multirow{2}{*}{$\begin{array}{l}\text { Sample } \\
\text { average }\end{array}$} & \multirow{2}{*}{$\begin{array}{l}\text { Sample } \\
\text { median }\end{array}$} & \multicolumn{5}{|c|}{ Compustat breakpoint quintiles } \\
\hline & & & & 1 & 2 & 3 & 4 & 5 \\
\hline \multirow{3}{*}{ Sales } & Universe avg. & & & 1.0 & 1.7 & 2.8 & 3.9 & 5.7 \\
\hline & Sample avg. & 2.2 & 2.0 & 1.0 & 2.0 & 3.0 & 4.5 & 6.6 \\
\hline & Sample \% & & & 40.6 & 26.8 & 20.4 & 9.3 & 2.9 \\
\hline \multirow{3}{*}{ Debt/Assets } & Universe avg. & & & 0.0 & 0.0 & 0.2 & 0.3 & 1.0 \\
\hline & Sample avg. & 0.3 & 0.2 & 0.0 & 0.1 & 0.2 & 0.3 & 0.7 \\
\hline & Sample \% & & & 19.8 & 17.2 & 16.3 & 22.7 & 24.1 \\
\hline \multirow{3}{*}{ Short Term Debt/Total Debt } & Universe avg. & & & 0.0 & 0.0 & 0.2 & 0.4 & 0.9 \\
\hline & Sample avg. & 0.3 & 0.1 & 0.0 & 0.0 & 0.2 & 0.4 & 0.9 \\
\hline & Sample \% & & & 25.9 & 11.7 & 28.2 & 18.7 & 15.5 \\
\hline \multirow{3}{*}{ Payout Ratio } & Universe avg. & & & & & 0.0 & & 55.6 \\
\hline & $\begin{array}{l}\text { Sample avg. } \\
(\%)\end{array}$ & 21.3 & 0.0 & & & 0.0 & & 41.7 \\
\hline & Sample \% & & & & & 50.2 & & 49.8 \\
\hline \multirow{3}{*}{ Credit Rating } & Universe avg. & & & 4.7 & 5.8 & 6.8 & 7.3 & 8.4 \\
\hline & Sample avg. & 8.4 & 9.0 & 3.6 & 6.0 & 7.0 & 8.0 & 9.6 \\
\hline & Sample \% & & & 7.5 & 8.4 & 7.8 & 16.5 & 59.8 \\
\hline \multirow{3}{*}{ Historical Growth } & Universe avg. & & & -0.2 & 0.0 & 0.1 & 0.2 & 1.7 \\
\hline & Sample avg. & 0.3 & 0.1 & -0.2 & 0.0 & 0.1 & 0.2 & 1.0 \\
\hline & Sample \% & & & 1.0 & 26.6 & 33.3 & 25.2 & 13.9 \\
\hline
\end{tabular}


APPENDIX A2 - Public Sample Firms

Comparison of the survey sample of publicly listed firms under management of US CEOs to the Compustat sample using survey variable definitions. Variable definitions as in Appendix A1

\begin{tabular}{|c|c|c|c|c|c|c|c|c|}
\hline \multicolumn{9}{|c|}{ Compare to Compustat Using Survey Variable Definitions } \\
\hline \multirow[b]{2}{*}{ Variable } & & \multirow{2}{*}{$\begin{array}{l}\text { Sample } \\
\text { average }\end{array}$} & \multirow{2}{*}{$\begin{array}{l}\text { Sample } \\
\text { median }\end{array}$} & \multicolumn{5}{|c|}{ Compustat breakpoint quintiles } \\
\hline & & & & 1 & 2 & 3 & 4 & 5 \\
\hline \multirow{3}{*}{ Sales } & Universe avg. & & & 1.0 & 1.7 & 2.8 & 3.9 & 5.7 \\
\hline & Sample avg. & 3.5 & 3.0 & 1.0 & 2.0 & 3.0 & 4.7 & 6.6 \\
\hline & Sample \% & & & 11.4 & 17.7 & 27.8 & 30.4 & 12.7 \\
\hline \multirow{3}{*}{ Debt/Assets } & Universe avg. & & & 0.0 & 0.0 & 0.2 & 0.3 & 1.0 \\
\hline & Sample avg. & 0.3 & 0.3 & 0.0 & 0.1 & 0.2 & 0.3 & 0.7 \\
\hline & Sample \% & & & 18.8 & 18.8 & 11.6 & 30.4 & 20.3 \\
\hline \multirow{3}{*}{ Short Term Debt/Total Debt } & Universe avg. & & & 0.0 & 0.0 & 0.2 & 0.4 & 0.9 \\
\hline & Sample avg. & 0.2 & 0.2 & 0.0 & 0.0 & 0.2 & 0.4 & 0.9 \\
\hline & Sample \% & & & 24.3 & 11.4 & 35.7 & 15.7 & 12.9 \\
\hline \multirow{3}{*}{ Payout Ratio } & Universe avg. (\%) & & & & & 0.0 & & 46.2 \\
\hline & Sample avg. (\%) & 19.1 & 5.0 & & & 0.0 & & 36.7 \\
\hline & Sample $\%$ & & & & & 53.2 & & 46.8 \\
\hline \multirow{3}{*}{ Credit Rating } & Universe avg. & & & 4.7 & 5.8 & 6.8 & 7.3 & 8.4 \\
\hline & Sample avg. & 7.9 & 8.0 & 4.5 & 6.0 & 7.0 & 8.0 & 9.6 \\
\hline & Sample \% & & & 7.7 & 17.3 & 13.5 & 23.1 & 38.5 \\
\hline \multirow{3}{*}{ Historical Growth } & Universe avg. & & & -0.2 & 0.0 & 0.1 & 0.2 & 1.7 \\
\hline & Sample avg. & 0.2 & 0.1 & -0.1 & 0.0 & 0.1 & 0.2 & 0.7 \\
\hline & Sample \% & & & 3.0 & 36.7 & 24.1 & 26.6 & 10.1 \\
\hline
\end{tabular}

